OPEN ACCESS

Edited by:

Takehito Ouchi,

Tokyo Dental College, Japan

Reviewed by:

Sina Naserian,

INSERM UMR-S-MD 1197, Hôpital

Paul Brousse, France

Louis Charles Penning,

Utrecht University, Netherlands

*Correspondence:

Mian Wan

mianwan@scu.edu.cn

Specialty section:

This article was submitted to

Stem Cell Research,

a section of the journal

Frontiers in Cell and Developmental

Biology

Received: 09 February 2021

Accepted: 06 April 2021

Published: 19 May 2021

Citation:

Cui D, Yu S, Zhou X, Liu Y, Gan L,

Pan Y, Zheng L and Wan M (2021)

Roles of Dental Mesenchymal Stem Cells in the Management of Immature

Necrotic Permanent Teeth.

Front. Cell Dev. Biol. 9:666186.

doi: 10.3389/fcell.2021.666186

\section{Roles of Dental Mesenchymal Stem Cells in the Management of Immature Necrotic Permanent Teeth}

\author{
Dixin Cui ${ }^{1}$, Sihan Yu' ${ }^{1}$, Xin Zhou ${ }^{1}$, Ying Liu ${ }^{1}$, Lu Gan ${ }^{1}$, Yue Pan ${ }^{1}$, Liwei Zheng ${ }^{1}$ and \\ Mian Wan ${ }^{2 *}$
}

1 State Key Laboratory of Oral Diseases, National Clinical Research Center for Oral Diseases, Department of Pediatric Dentistry, West China Hospital of Stomatology, Sichuan University, Chengdu, China, ${ }^{2}$ State Key Laboratory of Oral Diseases, National Clinical Research Center for Oral Diseases, Department of Cariology and Endodontics, West China Hospital of Stomatology, Sichuan University, Chengdu, China

Dental caries and trauma always lead to pulp necrosis and subsequent root development arrest of young permanent teeth. The traditional treatment, apexification, with the absence of further root formation, results in abnormal root morphology and compromises long-term prognosis. Regeneration endodontics procedures (REPs) have been developed and considered as an alternative strategy for management of immature permanent teeth with pulpal necrosis, including cell-free and cell-based REPs. Cell-free REPs, including revascularization and cell homing with molecules recruiting endogenous mesenchymal stem cells (MSCs), have been widely applied in clinical treatment, showing optimistic periapical lesion healing and continued root development. However, the regenerated pulp-dentin complex is still absent in these cases. Dental MSCs, as one of the essentials of tissue engineering, are vital seed cells in regenerative medicine. Dental MSC-based REPs have presented promising potential with pulp-dentin regeneration in large animal studies and clinical trials via cell transplantation. In the present review, we summarize current understanding of the biological basis of clinical treatments for immature necrotic permanent teeth and the roles of dental MSCs during this process and update the progress of MSC-based REPs in the administration of immature necrotic permanent teeth.

Keywords: dental mesenchymal stem cells, regenerative endodontics, pulp-dentin regeneration, immature permanent teeth, cell transplantation

\section{INTRODUCTION}

Immature permanent teeth are prone to pulpal necrosis due to caries, trauma, or developmental malformation. These cases always lead to arrest of root formation, accompanied by thin root dentinal walls and open apices, which has been a challenge in endodontics (Shabahang, 2012). With apexification, the traditional treatment, either calcium hydroxide or mineral trioxide aggregate (MTA) is applied to achieve apical sealing (Andreasen and Bakland, 2011; Nicoloso et al., 2017). Apexification has been reported to resolve apical periodontitis with a success rate of $74-100 \%$ (Al Ansary et al., 2009). However, absence of further root formation with apexification still results in abnormal root morphology, such as thin dentinal walls with an increased risk of root fracture, consequently compromising long-term prognosis (Rafter, 2004). 
Regeneration endodontics procedures (REPs) have been developed and considered as an alternative strategy for treatment of immature permanent teeth with pulp necrosis (Murray et al., 2006). The notion of tissue regeneration in the root canal was first proposed in the 1960s (Nygaard-Ostby, 1961). Banchs and Trope (2004) introduced a case report describing an alternative treatment for the management of necrotic immature permanent teeth called revascularization, in which a blood clot was induced inside the root canal after control of inflammation. Later, autologous platelet-rich plasma (PRP) and platelet-rich fibrin (PRF) took the place of the blood clot as alternative scaffolds because of their potential to induce tissue regeneration (Lovelace et al., 2010). A standard protocol for clinical REPs was proposed by the American Association of Endodontists [AAE], 2016b) in 2016 These REPs without exogenous cells, including revascularization and cell homing, have been successful in resolving apical periodontitis and arrest of root formation (Iwaya et al., 2001; Torabinejad and Turman, 2010; Shimizu et al., 2013). However, histological studies show that the pulpdentin complex is absent in these cases although some of them have shown vital pulp (Shimizu et al., 2013; Ulusoy et al., 2019). Desired REPs are supposed to eliminate apical periodontitis; increase root length, dentinal wall thickness, and apical closure; and restore homeostatic function of the pulp-dentin complex, including inherent immunity, tertiary dentin formation with stimulus, and pulp sensibility. In particular, the reinstitution of pulp-dentin structure functions prolongs the life of the tooth. Hence, scientists and endodontists are keen to develop a novel regenerative strategy to achieve pulp vitality and organized pulpdentin structure with homeostatic functions.

Three major elements have been recommended by Diogenes for further studies of pulp-dentin regeneration, including (i) reliable cell resources responsible for formation of root dentin, pulp tissue, and supporting tissue; (ii) an applicable scaffold to facilitate cellular proliferation and differentiation; and (iii) signaling molecules to motivate and direct tissue development, maturation, and neovascularization (Diogenes et al., 2016). Mesenchymal stem cells (MSCs) responsible for pulp-dentin regeneration might be indispensable for ideal REPs. Several preclinical studies reveal the regenerative potential of pulpdentin tissue via cultured cell transplantation (Nakashima et al., 2017; El Ashiry et al., 2018; Xuan et al., 2018). With its accessibility and unique potential in dental tissue regeneration, including the pulp-dentin complex, dental MSCs play a decisive role of seed cells in REPs. In this context, the applications of dental pulp stem cells (DPSCs), stem cells from human exfoliated deciduous teeth (SHED), stem cells from apical papilla (SCAP), periodontal ligament stem cells (PDLSCs), and dental follicle stem cells (DFSCs) have been explored. In the latest clinical study (Xuan et al., 2018), implantation of autologous SHED aggregates generated pulp-dentin complex in immature necrotic permanent incisors of pediatric patients, including functional dental pulp tissue regeneration with vasculature, innervation, and the lining odontoblast layer. The regenerated dental pulp tissue promotes root elongation and apical foramen closure. Therefore, dental MSCs exert therapeutic applications and are of great importance in treating immature necrotic permanent teeth.
In this review, we briefly summarize the current understanding of the biological basis of clinical treatments for immature permanent teeth with pulpal necrosis and the roles of dental MSCs during this process and update the progress of MSC-based REPs in the treatment of immature necrotic permanent teeth.

\section{BIOLOGICAL BASIS FOR REPS}

Root development relies on temporospatial reciprocal action between dental epithelium (Hertwig's epithelial root sheath, HERS) and mesenchyme from the cranial neural crest (dental papilla and follicle) (Thesleff and Sharpe, 1997). When the tooth crown is formed, HERS is formed by the inner and outer enamel epithelium of the enamel organ, which lies between the dental papilla and follicle. Then, HERS extends apically with the dental papilla and follicle and eventually regulates root formation. The inner epithelial cells of HERS induce MSCs at the periphery of the pulp to form odontoblasts, which produce the root dentin (Huang et al., 2009). As SHED fragments, the dental follicle penetrates into the epithelial fenestrations, contacts the root dentin, and differentiates into cementoblasts, which form the cementum covering the root dentin (Zeichner-David et al., 2003; Sonoyama et al., 2007b; Huang et al., 2009). The dental follicle is also responsible for the formation of periodontal ligament and fiber bundles. Hence, HERS plays a vital role in the interaction between the dental epithelial and dental mesenchymal compartment during root formation (Figure 1).

Arrested root formation in immature necrotic permanent teeth is always related to severe HERS damage due to dental trauma (Andreasen et al., 1988). Inflammatory cytokines and chemokines induced by severe and chronic inflammation impair the stem cells during tissue repair (Cooper et al., 2014). Additionally, function of SCAP could be disrupted by proinflammatory cytokines (Johnson, 1997; Liu et al., 2016; Wang et al., 2017). Hence, root formation is halted in immature permanent teeth with pulpal necrosis. Once inflammation is controlled, proinflammatory cytokine and chemokines are reduced, which leads to resumption of the regulatory effect of HERS and, consequently, induces the continued formation of the incomplete root (Cooper et al., 2010; Diogenes and Hargeraves, 2017). MSCs are vulnerable to the inflammatory microenvironment, and their immunomodulatory capacities can vary unexpectedly with the exposure to different inflammatory conditions (Noronha et al., 2019). It is demonstrated that the TNFa/TNFR2 signaling pathway is involved in regulating the immunomodulatory properties of MSCs (Beldi et al., 2020a,b). The TNF $\alpha-T N F R 2$ axis mediates MSCs' anti-inflammatory effects and cell survival, indicated by the inhibition of $\mathrm{T}$ cell proliferation, the production of proinflammatory cytokines, and the inductive activation of regulatory $\mathrm{T}$ cells. The presence of the TNFR2 molecule is also involved in the regulatory effect of MSCs, such as the colony-forming unit, proliferation, and MSCspecific surface markers. TNFR2 is expressed predominantly in endothelial progenitor cells. The TNF $\alpha / T N F R 2$ signaling pathway is also critical in the regulation of endothelial progenitor 


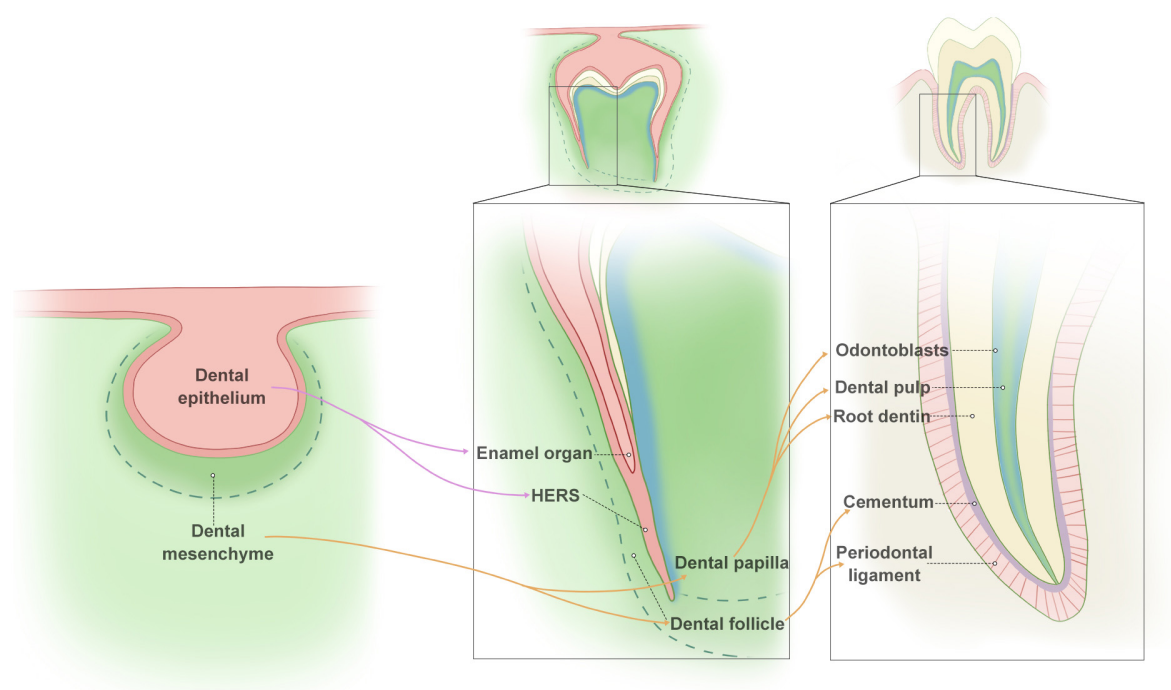

FIGURE 1 | Summary of root formation.

cell immunosuppression and the angiogenic effect to form new immunosuppressive vessels (Naserian et al., 2020). Whether the inflammatory environment caused by pulpal necrosis/apical periodontitis plays protective and essential roles in the biological functions of SCAPs needs further study. A previous study suggests the long-term viability of apical papilla under prolonged root canal infection and apical periodontitis (Diogenes and Hargeraves, 2017). On the contrary, MSCs responsible for the pulp-dentin complex in the root canal rarely survive during chronic endodontic infection, which explains the absence of pulp-dentin regeneration with revascularization or cell homing.

\section{DENTAL MESENCHYMAL STEM CELLS}

Human MSCs are multipotent cells from various tissues, such as skeletal muscle, adipose tissue, placenta, bone, and dental tissue (Pittenger et al., 1999). Based on minimal criteria proposed by the International Society for Cellular Therapy (ISCT), MSCs are plastic-adherent; possess multilineage differentiation potential in vitro; express at least CD105, CD73, and CD90; and negatively express CD11b, CD14, CD19, CD34, CD45, CD79 $\alpha$, and HLADR cell surface markers (Dominici et al., 2006; Han et al., 2019). According to MSC minimal criteria, dental MSCs derived from dental tissues, including impacted teeth and their supporting tissues, have been identified and characterized with typical MSC properties (Sharpe, 2016; Table 1). In addition to easy access, dental MSCs are genomically stable after multiple passages in vitro. Despite their multilineage differentiation capacity, dental MSCs are distinct from other MSCs because of the unique potential in dental tissue regeneration and have aroused much interest in regenerative medicine, especially the applications of REPs (Huang et al., 2009a). To date, dentin, dental pulp, or even pulp-dentin complex-like structure regenerations with the application of dental MSCs have been widely investigated, including DPSCs, SHED, SCAP, PDLSCs, and DFSCs.

\section{DPSCs}

Dental pulp tissue, formed by neural crest-derived dental papilla, is the soft tissue surrounded by the dentin. Responding to external stimuli, odontoblasts form the tertiary dentin. These odontoblasts are supposed to be derived from the progenitor cell populations within dental pulp. DPSCs, first isolated from adult third molar pulp tissues by Gronthos et al., possess definitive MSC characteristics, self-renewal capacity, and multilineage differentiation potential (Gronthos et al., 2000). DPSCs can differentiate into osteoblast-like cells with specific markers, forming new bone in vivo (Mortada and Mortada, 2018). A series of case reports indicate the potential application of DPSCs in treating intraosseous defects. In these patients with such defects caused by periodontitis, minimally invasive flap and collagen sponge integrated with autologous/allogeneic DPSCs have been applied. Results showed decreased probing depth reduction, achievement of clinical attachment, and formation of new bone with rare adverse effects, indicating the periodontal tissue regeneration potential of DPSCs (Aimetti et al., 2018; Ferrarotti et al., 2018; Hernández-Monjaraz et al., 2018). DPSCs are known to differentiate into odontoblasts that are indispensable for dentinogenesis. Dentin-like tissue is formed in vivo with DPSCs and hydroxyapatite/tricalcium phosphate (HA/TCP) scaffold, presenting a lining odontoblast-like cell layer of a specific odontoblastic-related marker expression, dentin sialophosphoprotein (DSPP) (Anitua et al., 2017; da Silva et al., 2019). Compared with human bone marrow MSCs, DPSCs exhibit notable neurogenic potential due to their origin of the neural crest and could differentiate into neurons upon specific differentiation induction (Pagella et al., 2019). The neurogenic potential was also confirmed with higher expression levels of neurotrophins when DPSCs were cocultured with trigeminal 
TABLE 1 | Comparison of root formation-related dental MSCs in immature permanent teeth.

\begin{tabular}{|c|c|c|c|c|c|}
\hline & Source & $\begin{array}{l}\text { Surface marker } \\
\text { positive }\end{array}$ & $\begin{array}{l}\text { Surface marker } \\
\text { negative }\end{array}$ & $\begin{array}{l}\text { Multi-lineage differentiation } \\
\text { potential }\end{array}$ & Immunomodulatory properties \\
\hline DPSCs & $\begin{array}{l}\text { Dental pulp } \\
\text { tissue of } \\
\text { permanent } \\
\text { teeth }\end{array}$ & $\begin{array}{l}\text { CD9, CD10, CD13, CD29, CD44, } \\
\text { CD59, CD73, CD90, CD105, CD106, } \\
\text { CD146, CD166, STRO-1, NANOG, } \\
\text { SOX2, OCT4, TRA1-60, TRA-1-80-1, } \\
\text { and Nestin }\end{array}$ & $\begin{array}{l}\text { CD14, CD19, } \\
\text { CD24, CD31, } \\
\text { CD34, CD45, and } \\
\text { CD117 }\end{array}$ & $\begin{array}{l}\text { odontoblasts, } \\
\text { osteoblasts, } \\
\text { chondrocytes, } \\
\text { adipocytes, } \\
\text { neurons, } \\
\text { cardiomyocyte, } \\
\text { and hepatocytes }\end{array}$ & $\begin{array}{l}\text { Immunosuppressive properties increased HGF, } \\
\text { TGF- } \beta, \text { PGE-2, IL-6, and IDO; decreased IL-4 } \\
\text { and IFN- } \gamma \text {; suppressed proliferation of T cells } \\
\text { and PBMCs; increased number of regulatory T } \\
\text { cells }\end{array}$ \\
\hline SHED & $\begin{array}{l}\text { Dental pulp } \\
\text { tissue of } \\
\text { exfoliated } \\
\text { deciduous } \\
\text { teeth }\end{array}$ & $\begin{array}{l}\text { CD13, CD29, CD44, CD73, CD90, } \\
\text { CD105, CD146, STRO-1, NANOG, adn } \\
\text { Nestin }\end{array}$ & $\begin{array}{l}\text { CD14, CD15, } \\
\text { CD19, CD34, and } \\
\text { CD45 }\end{array}$ & $\begin{array}{l}\text { odontoblasts, } \\
\text { osteocytes, } \\
\text { chondrocytes, } \\
\text { adipocytes, } \\
\text { neurons, } \\
\text { and hepatocytes }\end{array}$ & $\begin{array}{l}\text { Immunosuppressive properties increased IL-10; } \\
\text { decreased IL- } 4 \text { and IFN- } \gamma \text {; inhibited Th17 cell } \\
\text { differentiation; increased number of regulatory T } \\
\text { cells }\end{array}$ \\
\hline SCAP & $\begin{array}{l}\text { Apical } \\
\text { papilla }\end{array}$ & $\begin{array}{l}\text { CD13, CD24, CD29, CD44, CD49, } \\
\text { CD51, CD56, CD61, CD73, CD90, } \\
\text { CD106, CD146, CD166, STRO-1, } \\
\text { NANOG, and Nestin }\end{array}$ & $\begin{array}{l}\text { CD14, CD18, } \\
\text { CD34, and CD45 }\end{array}$ & $\begin{array}{l}\text { odontoblasts, } \\
\text { osteocytes, } \\
\text { adipocytes, } \\
\text { neurons, } \\
\text { and hepatocytes }\end{array}$ & $\begin{array}{l}\text { Low immunogenicity inhibited proliferation of } \mathrm{T} \\
\text { cells }\end{array}$ \\
\hline PDLSCs & $\begin{array}{l}\text { Periodontal } \\
\text { ligament }\end{array}$ & $\begin{array}{l}\text { CD9, CD10, CD13, CD29, CD44, } \\
\text { CD59, CD73, CD90, CD105 CD106, } \\
\text { CD146, CD166, and STRO-1 }\end{array}$ & $\begin{array}{l}\text { CD14, CD19, } \\
\text { CD34, CD45, and } \\
\text { HLA-DR }\end{array}$ & $\begin{array}{l}\text { cementoblasts, osteoblasts, } \\
\text { chondrocytes, adipocytes, and } \\
\text { neurons }\end{array}$ & $\begin{array}{l}\text { Immunosuppressive properties expressing } \\
\text { TLR2 and TLR4; released HGF, TGF- } \beta \text {, and } \\
\text { IDO; suppressed proliferation of PBMCs }\end{array}$ \\
\hline DFSCs & $\begin{array}{l}\text { Dental } \\
\text { follicle }\end{array}$ & $\begin{array}{l}\text { CD9, CD10, CD13, CD29, CD44, } \\
\text { CD59, CD73, CD90, CD105, CD106, } \\
\text { CD146, CD166, STRO-1, NANOG, } \\
\text { sox2, OCT4, and Nestin }\end{array}$ & $\begin{array}{l}\text { CD31, CD34, } \\
\text { CD45, and CD133 }\end{array}$ & $\begin{array}{l}\text { odontoblasts, cementoblasts, } \\
\text { osteoblasts, chondrocytes, } \\
\text { adipocytes, neurons, and } \\
\text { cardiomyocytes }\end{array}$ & $\begin{array}{l}\text { Immunosuppressive properties expressing } \\
\text { TLR2, TLR3, and TLR4; increased IL-6, TGF- } \beta \text {, } \\
\text { and IDO- } 1 \text {; decreased IFN- } \gamma \text {, IL-4, and IL-8; } \\
\text { suppressed proliferation and apoptosis of } \\
\text { PBMCs; increased number of regulatory T cells }\end{array}$ \\
\hline
\end{tabular}

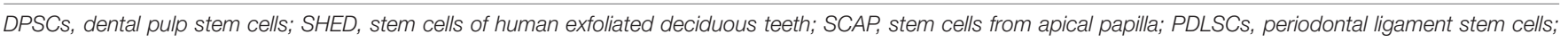

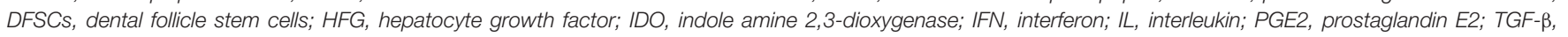
transforming growth factor beta; Th17, T-helper 17; TLR, Toll-like receptor; PBMCs, peripheral blood mononuclear cells.

neurons (Jung et al., 2016; Kawase-Koga et al., 2019). DPSCs also display angiogenic potential for differentiation potential of endothelial cells and the formation of blood vessels after in vivo transplantation with HA scaffold (Jeong et al., 2020). A clinical study shows that implanted DPSCs achieve pulplike tissue regeneration with vasculature and innervation in the root canal of traumatized incisors (Nakashima et al., 2017). The potential application of DPSCs in dental pulp tissue regeneration has also been indicated by another case report. The affected mature permanent tooth with symptomatic irreversible pulpitis shows a positive response in pulp vitality test, following the administration of autologous DPSCs and leukocyte PRF in the root canal of the affected tooth (Meza et al., 2018). The promising neurogenic, angiogenic, and odontoblastic differentiation potential makes DPSCs a major contributor to dentin regeneration and even whole pulp regeneration.

\section{SHED}

SHED were collected from children's exfoliated deciduous teeth with a similar methodology as that for DPSCs (Miura et al., 2003). SHED possess multilineage differentiation potential and can differentiate into various cell types, such as odontoblasts, adipocytes, and neurons (Miura et al., 2003). However, SHED show capacities of higher proliferation, more cell population doublings, and remarkable osteoinduction compared with DPSCs based on developmental differences between deciduous and permanent teeth. Regenerated new bone with larger osteoids and more collagen fibers by SHED with a polylactic-coglycolic acid membrane suggests that SHED exhibit outstanding potential for bone regeneration compared with DPSCs and bone marrow MSCs (Miura et al., 2003; Kunimatsu et al., 2018). As for the potential of neural regeneration, SHED show more intensive expression of neural differentiation markers than DPSCs under neural induction culture, such as $\beta$-III-tubulin and nestin (Wang et al., 2009) and can also promote neural functional recovery (Nicola et al., 2018). The odontoblastic differentiation capacity of SHED has been confirmed by in vivo transplantation that the composites of SHED and HA/TCP form a dentin-like structure containing DPSS-positive odontoblasts (Miura et al., 2003). SHED are also capable of forming functional dental pulp tissue, containing odontoblasts to regenerate tubular dentin in fulllength root canals combined with collagen type I (Cordeiro et al., 2008). The abovementioned odontoblastic differentiation capacity renders SHED a promising cell source for dentin or pulp regeneration; and whole dental pulp regeneration has been achieved by SHED (Xuan et al., 2018).

\section{SCAP}

In the process of tooth development, dental papilla forms dental pulp and migrates apically (Sonoyama et al., 2007b). Several clinical case reports show that root formation continues in some necrotic immature permanent teeth, indicating that 
TABLE 2 | Current preclinical and clinical studies of cell-free REPs.

\begin{tabular}{|c|c|c|c|c|c|c|c|}
\hline Study/year & $\begin{array}{l}\text { Sample size } \\
\text { (teeth) }\end{array}$ & $\begin{array}{l}\text { Animal } \\
\text { model }\end{array}$ & $\begin{array}{l}\text { Intracanal } \\
\text { medication }\end{array}$ & Scaffold & $\begin{array}{l}\text { Capping } \\
\text { material }\end{array}$ & $\begin{array}{l}\text { Observation } \\
\text { period }\end{array}$ & Results or outcomes \\
\hline \multicolumn{8}{|c|}{ Preclinical studies } \\
\hline $\begin{array}{l}\text { da Silva et al., } \\
2009\end{array}$ & 40 & Dogs & TAP & Empty scaffold & MTA & 90 days & $\begin{array}{l}\text { Hard tissue barrier, and increase of apical } \\
\text { periodontal ligament thickness }\end{array}$ \\
\hline $\begin{array}{l}\text { Yamauchi et al., } \\
2010\end{array}$ & 64 & Dogs & TAP & $\begin{array}{l}\text { Cross-linked collagen } \\
\text { scaffold + blood clot, } \\
\text { blood clot }\end{array}$ & MTA & 3.5 months & Periapical healing and root wall thickening \\
\hline $\begin{array}{l}\text { Tawfik et al., } \\
2013\end{array}$ & 108 & Dogs & TAP & $\begin{array}{l}\text { bFGF injectable } \\
\text { scaffold + blood clot, } \\
\text { blood clot }\end{array}$ & MTA & 3 months & $\begin{array}{l}\text { Negative results in this study: no change of root } \\
\text { length and root thickness. }\end{array}$ \\
\hline $\begin{array}{l}\text { Khademi et al., } \\
2014\end{array}$ & 36 & Dogs & TAP & Blood clot & MTA & 3-6 months & $\begin{array}{l}\text { periapical healing, apical closure, and dentinal } \\
\text { walls thickening }\end{array}$ \\
\hline Yoo et al., 2014 & 30 & Dogs & TAP & $\begin{array}{l}\text { a collagen scaffold } \\
\text { sponge (soaked with } \\
\text { conditioned media from } \\
\text { mouse preameloblasts) } \\
\text { + blood clot }\end{array}$ & MTA & 12 weeks & $\begin{array}{l}\text { Continuous growth of root dentin, and hard } \\
\text { tissue formation }\end{array}$ \\
\hline $\begin{array}{l}\text { Zhang et al., } \\
2014\end{array}$ & 27 & Dogs & TAP & PRP, blood blot & MTA & 3 months & Root canal walls thickening, and apical closure \\
\hline $\begin{array}{l}\text { Londero Cde } \\
\text { et al., } 2015\end{array}$ & 20 & Dogs & TAP & $\begin{array}{l}\text { Gelatin-based scaffold } \\
\text { (Gelfoam) + blood clot, } \\
\text { blood clot }\end{array}$ & MTA & 7 months & Increase in root length \\
\hline $\begin{array}{l}\text { Rodríguez- } \\
\text { Benítez et al., } \\
2015\end{array}$ & 40 & Dogs & $\begin{array}{c}\text { modified } \\
\text { triple- } \\
\text { antibiotics } \\
\text { paste (mTAP) }\end{array}$ & PRP, blood blot & MTA & 6 months & $\begin{array}{l}\text { Root dentinal walls thickening, hard tissue } \\
\text { deposition on dentinal walls, and apical closure }\end{array}$ \\
\hline $\begin{array}{l}\text { Saoud et al., } \\
2015\end{array}$ & 17 & Dogs & TAP & Blood clot & MTA & 3 months & $\begin{array}{l}\text { Not reported about root development and } \\
\text { apical closure; but significant dentinal walls } \\
\text { thickening, and periapical healing }\end{array}$ \\
\hline $\begin{array}{l}\text { Torabinejad } \\
\text { et al., } 2015\end{array}$ & 24 & Dogs & TAP & $\begin{array}{l}\text { Blood clot/Gelfoam, } \\
\text { PRP }\end{array}$ & MTA & 3 months & $\begin{array}{l}\text { Apical narrowing, and hard tissue deposition in } \\
\text { the apical third of the root }\end{array}$ \\
\hline $\begin{array}{l}\text { Altaii et al., } \\
2017\end{array}$ & 4 & Sheep & TAP & Blood clot & MTA & 6 months & $\begin{array}{l}\text { Significant increases in root length, root wall } \\
\text { thickness and narrowing of root canal apical } \\
\text { diameter }\end{array}$ \\
\hline Study/year & $\begin{array}{c}\text { Sample size } \\
\text { (teeth) }\end{array}$ & $\begin{array}{c}\text { Age of } \\
\text { patients } \\
\text { (mean } \pm S D)\end{array}$ & $\begin{array}{l}\text { Intracanal } \\
\text { medication }\end{array}$ & Scaffold & $\begin{array}{l}\text { Capping } \\
\text { material }\end{array}$ & $\begin{array}{l}\text { Observation } \\
\text { period } \\
\text { (mean } \pm \text { SD) }\end{array}$ & Results or outcomes \\
\hline
\end{tabular}

\begin{tabular}{|c|c|c|c|c|c|c|c|}
\hline \multicolumn{8}{|l|}{ Clinical studies } \\
\hline $\begin{array}{l}\text { Reynolds et al., } \\
2008\end{array}$ & 2 & 11 years old & TAP & Blood clot & MTA & 18 months & $\begin{array}{l}\text { Significant root development with maturation of } \\
\text { the dentin }\end{array}$ \\
\hline $\begin{array}{l}\text { Bose et al., } \\
2009\end{array}$ & 88 & - & $\begin{array}{c}\text { TAP, } \\
\mathrm{Ca}(\mathrm{OH}) 2 \text {, and } \\
\text { formocresol }\end{array}$ & Blood clot & MTA & $\begin{array}{l}6 \text { months- } \\
36 \text { months }\end{array}$ & $\begin{array}{l}\text { Continued root development: increased } \\
\text { percentage of root length and dentinal wall } \\
\text { thickness }\end{array}$ \\
\hline $\begin{array}{l}\text { Ding et al., } \\
2009\end{array}$ & 12 & $\begin{array}{l}8-11 \text { years } \\
\text { old }\end{array}$ & TAP & Blood clot & MTA & 15 months & $\begin{array}{l}3 \text { teeth of } 12 \text { exhibit complete root } \\
\text { development with closed apex and positive } \\
\text { response to electric pulp testing }\end{array}$ \\
\hline $\begin{array}{l}\text { Petrino et al., } \\
2009\end{array}$ & 6 & $\begin{array}{l}6,11, \text { and } \\
13 \text { years old }\end{array}$ & TAP & Blood clot & MTA & $6-12$ months & $\begin{array}{l}3 \text { of } 6 \text { teeth showed continued root } \\
\text { development, and } 2 \text { teeth displayed positive } \\
\text { response to vitality testing }\end{array}$ \\
\hline $\begin{array}{l}\text { Iwaya et al., } \\
2010\end{array}$ & 1 & 7 years old & $\begin{array}{l}\mathrm{Ca}(\mathrm{OH})_{2} \\
\text { paste } \\
\text { (Vitapex) }\end{array}$ & Empty scaffold & $\begin{array}{l}\text { Gutta- } \\
\text { percha }\end{array}$ & 30 months & $\begin{array}{l}\text { Continued root development, root apex } \\
\text { closure, and root canal thickness increase }\end{array}$ \\
\hline $\begin{array}{l}\text { Thomson and } \\
\text { Kahler, } 2010\end{array}$ & 1 & 12 years old & TAP & Blood clot & MTA & 18 months & Continued root maturation and apical closure \\
\hline $\begin{array}{l}\text { Torabinejad and } \\
\text { Turman, } 2010\end{array}$ & 1 & 11 years old & TAP & PRP & MTA & 5.5 months & $\begin{array}{l}\text { Periapical lesion resolution, further root } \\
\text { development, and continued apical closure of } \\
\text { the root apex }\end{array}$ \\
\hline
\end{tabular}


TABLE 2 | Continued

\begin{tabular}{|c|c|c|c|c|c|c|c|}
\hline Study/year & $\begin{array}{l}\text { Sample size } \\
\text { (teeth) }\end{array}$ & $\begin{array}{c}\text { Age of } \\
\text { patients } \\
\text { (mean } \pm S D)\end{array}$ & $\begin{array}{l}\text { Intracanal } \\
\text { medication }\end{array}$ & Scaffold & $\begin{array}{l}\text { Capping } \\
\text { material }\end{array}$ & $\begin{array}{l}\text { Observation } \\
\text { period } \\
\text { (mean } \pm \text { SD) }\end{array}$ & Results or outcomes \\
\hline $\begin{array}{l}\text { Chen et al., } \\
2011\end{array}$ & 20 & $\begin{array}{l}\text { 8-13 years } \\
\text { old }\end{array}$ & $\mathrm{Ca}(\mathrm{OH})_{2}$ & Blood clot & MTA & 6-26 months & $\begin{array}{l}\text { periapical wound healing, and Increased } \\
\text { thickening of root canal walls; } 15 \text { of } 20 \text { teeth } \\
\text { continued root development } \\
\text {; } 4 \text { of } 20 \text { teeth exhibited severe hard tissue } \\
\text { calcification in pulp canal; } 2 \text { of } 20 \text { teeth formed } \\
\text { a hard tissue barrier in root canal space }\end{array}$ \\
\hline $\begin{array}{l}\text { Nosrat et al., } \\
2011\end{array}$ & 2 & $\begin{array}{l}8, \text { and } \\
9 \text { years old }\end{array}$ & TAP & Blood clot & $\begin{array}{l}\text { Calcium } \\
\text { enriched } \\
\text { mixture } \\
\text { (CEM) }\end{array}$ & 15-18 months & $\begin{array}{l}\text { Periapical radiolucent lesions healing, and } \\
\text { continued roots development }\end{array}$ \\
\hline $\begin{array}{l}\text { Jeeruphan } \\
\text { et al., } 2012\end{array}$ & 20 & $\begin{array}{l}\text { 8-24 years } \\
\text { old }\end{array}$ & TAP & Blood clot & MTA & $\begin{array}{l}21.15 \pm 11.70 \\
\text { months }\end{array}$ & $\begin{array}{l}\text { Increased percentage of root width and root } \\
\text { length }\end{array}$ \\
\hline Kim et al., 2012 & 3 & $\begin{array}{l}10 \text { and } \\
12 \text { years old }\end{array}$ & TAP & Blood clot & MTA & $\begin{array}{l}24,42, \text { and } \\
48 \text { months }\end{array}$ & $\begin{array}{l}\text { Periapical radiolucency disappeared, and root } \\
\text { wall thickness increased }\end{array}$ \\
\hline $\begin{array}{l}\text { Martin et al., } \\
2012\end{array}$ & 1 & 9 years old & TAP & PRP + Blood clot & MTA & $\begin{array}{l}2 \text { years and } \\
1 \text { months }\end{array}$ & $\begin{array}{l}\text { Resolution of apical periodontitis; hard tissue of } \\
\text { obliteration in distal canal, reduction in size of } \\
\text { mesial canal space }\end{array}$ \\
\hline $\begin{array}{l}\text { Jadhav et al., } \\
2013\end{array}$ & 6 & $\begin{array}{l}10,13, \text { and } \\
23 \text { years old }\end{array}$ & TAP & $\begin{array}{l}\text { PRP + blood clot, } \\
\text { blood clot }\end{array}$ & $\begin{array}{c}\text { Resin } \\
\text { modified } \\
\text { glass } \\
\text { ionomer } \\
\text { cement }\end{array}$ & 12 months & $\begin{array}{l}\text { Periapical healing, apical closure, and dentinal } \\
\text { wall thickening }\end{array}$ \\
\hline $\begin{array}{l}\text { Kahler et al., } \\
2013\end{array}$ & 16 & $\begin{array}{l}\text { 7-12 years } \\
\text { old }\end{array}$ & TAP & Blood clot & MTA & 18 months & $\begin{array}{l}\text { Patterns of continued root maturogenesis were } \\
\text { variable: } 90.3 \% \text { resolution of the periapical } \\
\text { radiolucency, } 47.2 \% \text { incomplete apical closure, } \\
19.4 \% \text { complete apical closure, } 2.7 \% \text { to } 25.3 \% \\
\text { change of root length, and } 1.9 \% \text { to } 72.6 \% \\
\text { change of root dentin thickness }\end{array}$ \\
\hline $\begin{array}{l}\text { Nagy et al., } \\
2013\end{array}$ & 36 & $\begin{array}{l}9-13 \text { years } \\
\text { old }\end{array}$ & TAP & $\begin{array}{l}\text { FGF + blood clot, } \\
\text { blood clot }\end{array}$ & MTA & $\begin{array}{l}18 \text { months - } \\
3 \text { years }\end{array}$ & $\begin{array}{l}\text { Periapical healing, increase in root length and } \\
\text { width, and a decrease in apical diameter }\end{array}$ \\
\hline $\begin{array}{l}\text { Shimizu et al., } \\
2013\end{array}$ & 1 & 9 years old & $\mathrm{Ca}(\mathrm{OH})_{2}$ & Blood clot & MTA & 26 months & $\begin{array}{l}\text { Resolution of periapical lesion, continued root } \\
\text { development, thickening of the canal walls }\end{array}$ \\
\hline $\begin{array}{l}\text { Sönmez et al., } \\
2013\end{array}$ & 3 & 9 years old & TAP & Blood clot & MTA & 24 months & $\begin{array}{l}\text { Continued thickening of the dentinal walls with } \\
\text { apical closure; complete resolution of periapical } \\
\text { radiolucencies }\end{array}$ \\
\hline $\begin{array}{l}\text { Alobaid et al., } \\
2014\end{array}$ & 31 & $\begin{array}{l}6-16 \text { years } \\
\text { old }\end{array}$ & $\begin{array}{l}\text { TAP, BAP, } \\
\mathrm{Ca}(\mathrm{OH})_{2}\end{array}$ & Blood clot & MTA & $\begin{array}{l}14.5 \pm 8.5 \\
\text { months }\end{array}$ & $\begin{array}{l}\text { Apical closure and hard tissue barrier; but a } \\
\text { greater incidence of adverse events in } \\
\text { revascularization group }\end{array}$ \\
\hline $\begin{array}{l}\text { Bezgin et al., } \\
2014\end{array}$ & 22 & $\begin{array}{l}7-13 \text { years } \\
\text { old }\end{array}$ & TAP & PRP, blood clot & MTA & 18 months & $\begin{array}{l}\text { Complete apical closure, periapical tissue } \\
\text { pathology resolution }\end{array}$ \\
\hline $\begin{array}{l}\text { Nagata et al., } \\
2014\end{array}$ & 23 & $\begin{array}{l}\text { 7-17 years } \\
\text { old }\end{array}$ & $\begin{array}{l}\text { TAP, } \\
\mathrm{Ca}(\mathrm{OH})_{2} \text {, and } \\
\text { chlorhexidine }\end{array}$ & Blood clot & MTA & 9-19 months & $\begin{array}{l}\text { Periapical repair, apical closure, root length } \\
\text { increase, dentinal walls thickening; but crown } \\
\text { discoloration in teeth of TAP group }\end{array}$ \\
\hline $\begin{array}{l}\text { Saoud et al., } \\
2014\end{array}$ & 20 & $\begin{array}{l}11.3 \pm 1.9 \\
\text { years old }\end{array}$ & TAP & Blood clot & MTA & 1 year & $\begin{array}{l}\text { Increase in radiographic root width and length } \\
\text { and decrease in apical diameter }\end{array}$ \\
\hline $\begin{array}{l}\text { Narang et al., } \\
2015\end{array}$ & 20 & $\begin{array}{l}\text { Below } \\
20 \text { years old }\end{array}$ & TAP & $\begin{array}{l}\text { RPF + blood clot, } \\
\text { PRP + collagen, blood } \\
\text { clot }\end{array}$ & $\begin{array}{l}\text { Resin- } \\
\text { modified } \\
\text { glass } \\
\text { ionomer } \\
\text { cement }\end{array}$ & 6-18 months & $\begin{array}{l}\text { PRF shows significant periapical healing, apical } \\
\text { closure, root lengthening, and dentinal wall } \\
\text { thickening in revascularization treatment }\end{array}$ \\
\hline $\begin{array}{l}\text { Nosrat et al., } \\
2015\end{array}$ & 2 & $\begin{array}{l}9,10 \text { years } \\
\text { old }\end{array}$ & TAP & Blood clot & MTA & 4 months & $\begin{array}{l}\text { Progression of root development and } \\
\text { maturation of the roots }\end{array}$ \\
\hline $\begin{array}{l}\text { Timmerman } \\
\text { and Parashos, } \\
2016\end{array}$ & 1 & 16 years old & $\mathrm{Ca}(\mathrm{OH})_{2}$ & Blood clot & MTA & 3 years & $\begin{array}{l}\text { Complete periapical healing, thickening of the } \\
\text { dentinal root walls, and completed apex } \\
\text { formation }\end{array}$ \\
\hline $\begin{array}{l}\text { Austah et al., } \\
2018\end{array}$ & 2 & $\begin{array}{l}8, \text { and } \\
10 \text { years old }\end{array}$ & $\mathrm{BAP}, \mathrm{Ca}(\mathrm{OH})_{2}$ & Blood clot + CollaPlug & MTA & 43-54 months & $\begin{array}{l}\text { Complete healing of periapical tissues, } \\
\text { continued root development, root length } \\
\text { increase, and dentin thickness increase }\end{array}$ \\
\hline
\end{tabular}


TABLE 2 | Continued

\begin{tabular}{|c|c|c|c|c|c|c|c|}
\hline Study/year & $\begin{array}{l}\text { Sample size } \\
\text { (teeth) }\end{array}$ & $\begin{array}{c}\text { Age of } \\
\text { patients } \\
\text { (mean } \pm \text { SD) }\end{array}$ & $\begin{array}{l}\text { Intracanal } \\
\text { medication }\end{array}$ & Scaffold & $\begin{array}{l}\text { Capping } \\
\text { material }\end{array}$ & $\begin{array}{l}\text { Observation } \\
\text { period } \\
\text { (mean } \pm \text { SD) }\end{array}$ & Results or outcomes \\
\hline $\begin{array}{l}\text { Ajram et al., } \\
2019\end{array}$ & 1 & 7 years old & $\mathrm{Ca}(\mathrm{OH})_{2}$ & Blood clot & $\begin{array}{l}\text { Micro } \\
\text { Mega- } \\
\text { MTA } \\
\text { (MM- } \\
\text { MTA) }\end{array}$ & 2 years & $\begin{array}{l}\text { Complete apical healing, continued root } \\
\text { growth, and apical closure }\end{array}$ \\
\hline $\begin{array}{l}\text { Rizk et al., } \\
2019\end{array}$ & 26 & $\begin{array}{l}\text { 8-14 years } \\
\text { old }\end{array}$ & TAP & PRP, blood clot & MTA & 12 months & $\begin{array}{l}\text { Significant increase in root length, root width, } \\
\text { and decrease in apical diameter of PRP-treated } \\
\text { teeth compared with blood clot group; but } \\
\text { higher amount of crown discoloration in blood } \\
\text { clot-treated teeth }\end{array}$ \\
\hline $\begin{array}{l}\text { Alasqah et al., } \\
2020\end{array}$ & 1 & 8 years old & $\mathrm{Ca}(\mathrm{OH})_{2}, \mathrm{TAP}$ & Blood clot & MTA & 24 months & $\begin{array}{l}\text { Periapical healing with increased root thickness } \\
\text { and length, and complete apical closure }\end{array}$ \\
\hline
\end{tabular}

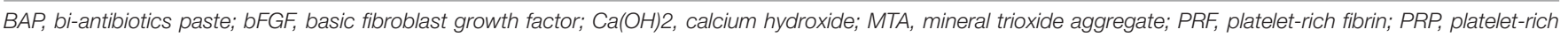
plasma; TAP, triple-antibiotics paste.

MSCs in apical papilla contribute to root development. SCAP are obtained from apical papilla of immature tooth roots and exhibit MSC properties, including expression of MSC surface markers and differentiation potential to a wide variety of cell types (Sonoyama et al., 2006, 2007a). SCAP possess neural differentiation potential similar to DPSCs and SHED, partially attributed to their common origin from the neural crest, and could be an alternative future therapy for spinal cord injury (De Berdt et al., 2015). Interestingly, SCAP have higher proliferation and greater odontoblastic differentiation potential than DPSCs, suggesting their potential applications for dentin regeneration (Sonoyama et al., 2006). In vivo studies show that SCAP are able to differentiate into odontoblast-like cells and generate dentin-like tissue with DSP expression (Sonoyama et al., 2006, 2007a). The dentin regeneration capacity of SCAP via cell homing strategy is enhanced by their greater migration ability following a scratch assay. SCAP can also form ectopic vascularized pulplike tissue with DSPP and dentin matrix protein 1 (DMP1)positive odontoblasts in mouse molars without exogenous growth factor application (Pelissari et al., 2018). Owing to their critical role in root development, SCAP are supposed to make a major contribution to root regeneration. After transplantation of SCAP and PDLSCs into a minipig model with a lower incisor extracted, a functional bioroot with root/periodontallike complex was formed. Mineralized root-like tissue is able to support a porcelain crown and perform normal tooth function (Sonoyama et al., 2006).

\section{PDLSCs}

A population of MSCs exists in the periodontal ligament (PDL), and it is responsible for periodontal tissue homeostasis and regeneration (McCulloch and Melcher, 1983; Seo et al., 2004). These cells were first isolated from the PDL of third molars and named PDLSCs. The cementogenic/osteogenic differentiation potential is indicated by the formation of mineralization nodules with the expression of bone-specific markers after in vivo transplantation (Seo et al., 2004). The cementogenic/osteogenic differentiation potential and PDL tissue regeneration potential of PDLSCs are shown in a rat model of periodontal lesions, confirmed by newly formed cementum/PDL-like structures at the lesion area, such as Sharpey's fiber-like tissue (Seo et al., 2004; Iwata et al., 2010). A recent preclinical study using a novel cell transfer technology demonstrates the potential of PDLSCs in periodontal regeneration. In a rat model of surgical periodontal defects, the transplantation of PDLSC-amniotic membrane composite enhanced the periodontal defect recovery, manifested as newly formed PDL, bone, and cementum at surgically defective sites (Iwasaki et al., 2019).

\section{DFSCs}

Dental follicle contributes to alveolar bone formation during tooth development, and contains an MSC population to form supporting tissues, named DFSCs. DFSCs were separated from the dental follicle of developing teeth (Morsczeck et al., 2004; Han et al., 2009; Zhou et al., 2019). Compared with DPSCs, SHED, and PDLSCs, DFSCs show a higher proliferation and colony-forming capacity, indicating their application potential in regenerative medicine (Tian et al., 2015; Yildirim et al., 2016). DFSCs also exhibit superior osteogenic properties compared with DPSCs and SHED as shown by the higher expression levels of osteogenic genes (Yildirim et al., 2016). Under the administration of differentiation induction culture medium, DFSCs form osteoblasts and produce mineralized nodules with osteogenic differentiation marker expression, bone sialoprotein, and osteocalcin (Morsczeck et al., 2004; Han et al., 2009). DFSCs are capable of periodontal differentiation, indicated by the formation of PDL-like tissues or mineralized structures with bone- or cementum-like tissues (Morsczeck et al., 2004; Han et al., 2009). DFSCs generate complex tissues similar to cementum-PDL complex in vivo, in which PDL-like collagen fibers are inserted into newly formed cementum-like tissue (Han et al., 2009). The potential of odontoblastic differentiation has also been suggested in DFSCs because they have been shown to express higher level of DSPP compared with PDLSCs. The formation of dentin, including dentin, predentin, and calcospherites, is observed with treated dentin matrix induction 
(Trubiani et al., 2019). All these findings suggest DFSCs as promising seed cells for both dentin and root regeneration.

\section{CELL-FREE REPS}

\section{Roles of Dental MSCs in Cell-Free REPs}

The first attempt at dental pulp tissue regeneration was proposed by Nygaard-Otsby et al. (Nygaard-Ostby, 1961; Nygaard-Ostby and Hjortdal, 1971). Over-instrumentation was applied to introduce blood from the periapical tissues into the root canal, followed by tissue growth. Later, Banchs and Trope (2004) proposed a protocol termed revascularization based on the experiments of Kling et al. (1986) on implanted teeth, Hoshino et al. (1996) on root canal disinfection, and (Nygaard-Ostby and Hjortdal, 1971) on blood clots in the canal space.

The standard REP protocol proposed by the American Association of Endodontists [AAE] (2016b; 2018) involves a multistep procedure. The first visit focuses on infection control of the affected tooth with the administration of a proper access cavity, canal irrigation, and disinfection. The common root canal dressing is calcium hydroxide or triple antibiotic paste (TAP), which is a mixture of ciprofloxacin, metronidazole, and minocycline. The second appointment aims to form the suitable scaffold formation for fresh tissue ingrowth and permanent coronal restoration following the absence of clinical signs and symptoms. During this appointment, the root canal is thoroughly irrigated with ethylenediaminetetraacetic acid to release the growth factor from the dentin. Apical bleeding is then stimulated by gentle irritation with a precurved K-file at $2 \mathrm{~mm}$ past the apical foramen to form a blood clot in the root canal. Finally, capping material, usually MTA, is placed over the blood clot, followed by the permanent coronal seal to prevent bacterial reinfection. At the follow-up, eliminating clinical signs and symptoms and healing periapical lesion are considered as primary goal of REPs. It is desirable, but not essential, that REPs increase the thickness of the root wall and/or length of the roots, which is the secondary goal. Some cases report that the teeth showed a positive response to pulp vitality testing, suggesting organized pulp tissue in the root canal, which achieves the tertiary goal.

As an amelioration to revascularization with blood clots, the cell homing strategy has been proposed to regenerate dental tissue via a cell-free strategy in which molecules encourage recruitment of the patient's endogenous MSCs to the rootcanal space (He et al., 2016; Yin et al., 2017). Several endodontists believe that cell homing is conducive to achieving a more effective strategy of pulp-dentin regeneration than simple revascularization without exogenous cell transplantation (Table 2). Several molecules, including basic fibroblast growth factors, vascular endothelial growth factors, platelet-derived growth factors, nerve growth factors, and bone morphogenetic protein 7 , have been applied as homing factors, showing promising outcomes in preclinical studies (Kim et al., 2010). These REPs without exogenous cell transplantation, including revascularization and cell homing, are considered cell-free REPs. Survival rates of cell-free REPs are reported close to $100 \%$ in some studies. Therefore, these studies suggest that cell-free
REPs have an obvious therapeutic effect on necrotic immature teeth (Figure 2A).

Stem cells, homing to the injury site, have an essential role in wound healing (Rustad and Gurtner, 2011). The cells in the sites of injury and inflammation release chemokines, stem cell factors, and growth factors, which motivate the cell homing (Eramo et al., 2018). CXCR4 ${ }^{+}$SCAP are demonstrated to be chemoattracted by stromal derived factor 1 , a chemokine, and migrate into a scaffold made of collagen gel (Liu et al., 2015). In cell-free REPs, stem cells from the periapical tissues get into the root canal space in various ways, mainly by periapical bleeding and molecules in the scaffolds. It is demonstrated that a large number of MSCs with expression of CD105, CD73, and STRO1 were induced into the empty root canal by importing periapical bleeding (Lovelace et al., 2010). These cells were supposed to be MSCs from the adjacent apical papilla rather than systemic circulation although no direct evidence is shown in that study. Additionally, histological and immunohistochemical analysis presented the formation of cementum- and bone-like structures in necrotic immature permanent teeth with cell-free REPs. It suggests that stem/progenitor cells in periapical tissue, responsible for production of cementum and bone, also entered the root canal and participated in the formation of mineralized tissue during continued root formation (Martin et al., 2012; Shimizu et al., 2012, 2013; Torabinejad and Faras, 2012; Becerra et al., 2013; Nosrat et al., 2015). Therefore, undifferentiated MSCs originated from apical papilla, and periapical tissues are considered to be major cell sources for continued root formation and pulp-dentin regeneration. Cells from distant site, such as systemic circulation, are considered to be cell sources for cellfree REPs. However, these cells make little contribution to pulp regeneration, considering their small numbers.

\section{Limitations of Cell-Free REPs}

Although cell-free REPs are suggested to be effective in eliminating apical periodontitis and even revitalization of nonvital immature teeth in some case reports, their outcomes are still unpredictable. Elimination of apical periodontitis associated with necrotic immature permanent teeth, the primary goal of REPs, can be easily achieved once the infection in the root canal is controlled with disinfection. However, the vitality of cells in apical papilla, dental follicle, and HERS is determined by severity, origin, and duration of inflammation from immature permanent teeth with pulpal necrosis, which is beyond the control of the endodontists. Once severe damage happens to the apical papilla or follicle, there are no dental MSCs supporting odontoblast differentiation or dentin formation, which results in a lack of continued root formation (Figure 3). It is impossible to clearly define the status of MSCs in the apical papilla and dental follicle; thus, endodontists in the clinic always fail to predict the outcomes of cell-free REPs in the necrotic immature permanent teeth.

American Association of Endodontists [AAE] (2016a) has defined REPs as "biologically based procedures designed to physiologically replace damaged tooth structures, including dentine and root structures, as well as cells of the pulp dentin complex." This suggests that endogenous stem cells introduced by periapical bleeding might achieve pulp-dentin 


\section{A. Cell-free REPs}

\section{Revascularization}

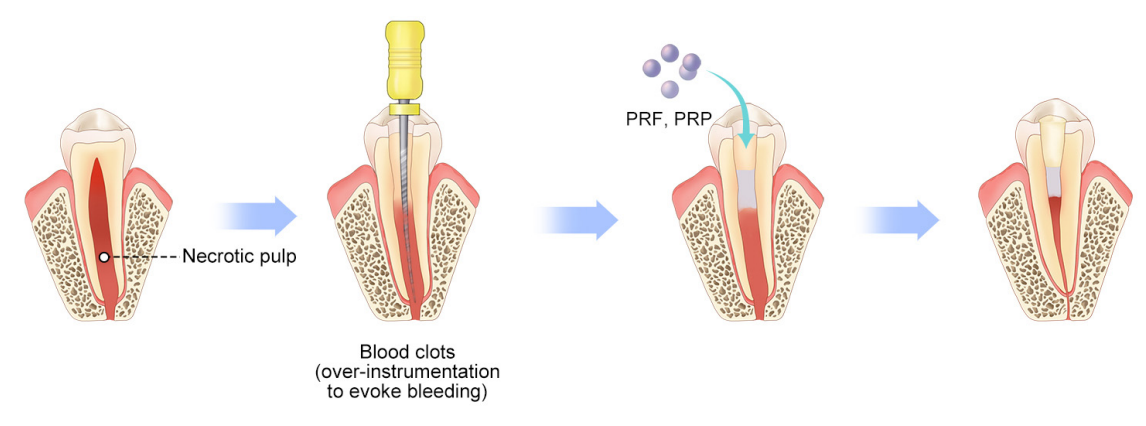

\section{Cell homing}
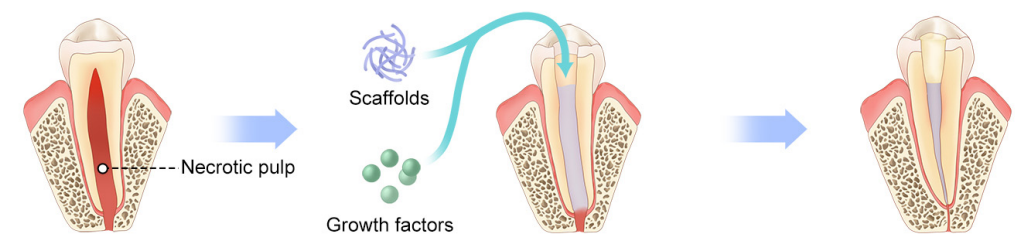

\section{B. Cell-based REPs}
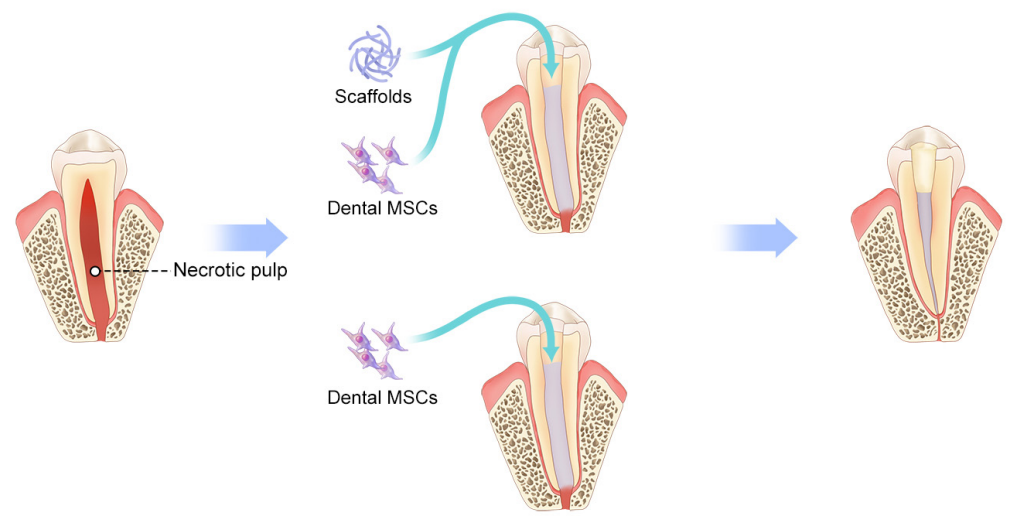

FIGURE 2 | Schematic diagram of REPs. (A) Cell-free REPs. (B) Cell-based REPs. REPs, regeneration endodontics procedures.

regeneration, which produce odontoblast-like cells and form dentin. However, both animal and preclinical studies fail to show such results. Formation of bone, cementum, and fibrous tissue is observed with revascularization in dogs. The regeneration of the pulp-dentin complex is rarely detected in the root canal. Additionally, histological studies of human teeth present similar cementum apposition, ectopic bone, and fibrous tissues in human mandibular molars treated with revascularization (Torabinejad and Faras, 2012; Nosrat et al., 2015). Only one human study shows regenerated pulp-dentin complex with odontoblast-like cells and dentinlike tissue in necrotic immature permanent teeth with cellfree REPs, which is assigned to survival of odontoblasts in the root canal (Austah et al., 2018). These studies suggest that the cell-free REPs of necrotic immature permanent teeth are "repair" rather than "regeneration" procedures (Diogenes et al., 2016). Unlike immature teeth with pulpal necrosis, teeth with reversible or irreversible pulpitis can regenerate pulpdentin complex after cell-free REPs. This might result from the remaining pulp tissue, which means the presence of MSCs 

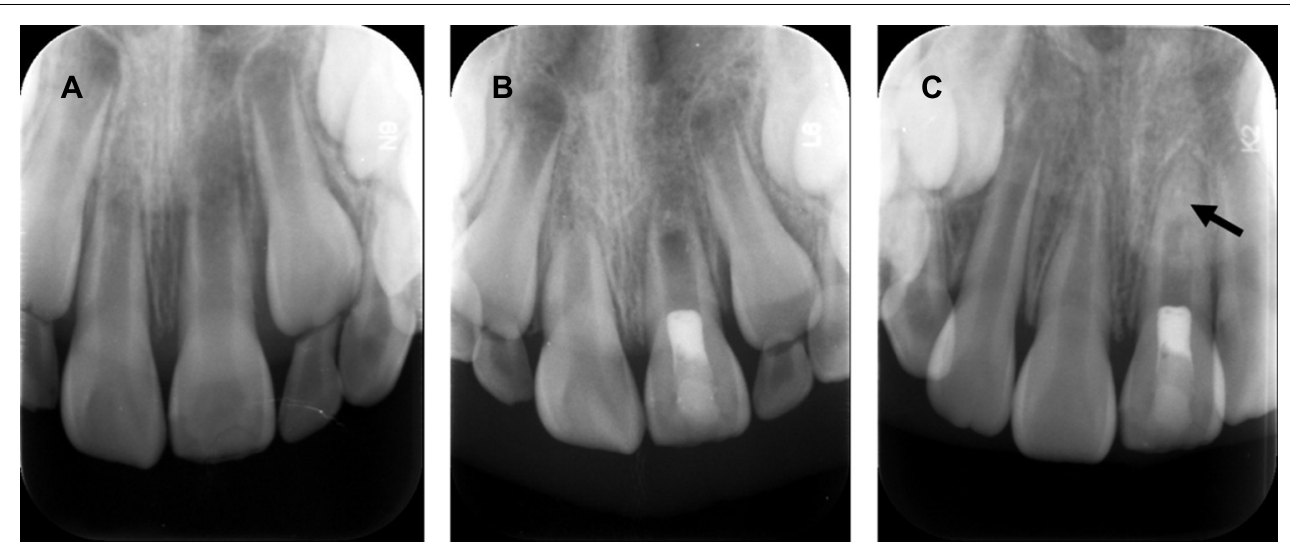

FIGURE 3 | Revascularization promotes continued root development and resolution of periapical lesion, but disorganized radio-opaque changes occur within the apical root canal. (A) Radiograph of a maxillary left central incisor: immature root formation with a wide-open apex and periapical lesion. (B) Postoperative radiograph of revascularization and coronal restoration. (C) Radiograph of one-year follow-up: resolution of periapical lesion and root apex closure. Arrow: non-specific radio-opaque calcific deposit within apical root canal. Courtesy of Dr. Xin Zhou.

responsible for pulp-dentin complex is indispensable for true regeneration in endodontics.

\section{CELL-BASED REPs}

\section{Roles of Dental MSCs in Cell-Based REPs}

Mooney et al. (1996) achieved cell-based pulp regeneration by applying pulp cells and polyglycolic acid in vitro as early as 1996. In 2005, stem cells were introduced as one of the essential elements of pulp-dentin regeneration in endodontics by Nakashima and Akamine (2005). Soon afterward, Murray et al. (2006) proposed regenerative endodontics as biologically based procedures, in which stem cells play a vital role. Since then, some studies demonstrate the effectiveness of cultured stem cell transplantation in pulp-dentin regeneration (Table 3). Huang et al. (2010) reported that MSC transplantation regenerated pulp-dentin complex in human root fragments compared with formation of fibrous tissue with scaffold alone, which was the first in vivo study of pulp-dentin regeneration. Pulp-dentin complex, a layer of odontoblast-like cells on nascent mineralized tissue, is observed in dental MSC-transplanted human dentin with polylactic acid, suggesting a requirement for cell transplantation in pulp-dentin regeneration (Sakai et al., 2010). Later, the necessity of cell transplantation was confirmed with animal studies. Pulp-dentin complex regeneration in large animals was first reported by Iohara et al. (2009) in a pulpotomy model in dogs, in which fractionated side-population cells enriched with $\mathrm{CD} 31^{-} / \mathrm{CD} 146^{-}$were transplanted. They also indicate that pulp tissue is regenerated in the root canal with a combination of CD105 ${ }^{+}$DPSCs and SDF-1 (Iohara et al., 2010). SDF-1 is considered an important homing signal by recruiting MSCs to injury sites and facilitating regeneration in various tissues (Suzuki et al., 2011). However, pulp tissue is hardly detected in the root canal with SDF-1 alone. These studies further demonstrate that homing signaling alone is insufficient for pulp-dentin regeneration. The transplantation of pulpal MSCs into the root canal is necessary for pulp-dentin regeneration (Figure 2B).

In recent years, cell-based REPs have aroused growing concern for pulpless teeth. Several clinical studies demonstrate whole dental pulp regeneration. In a preclinical trial, a composite containing human mobilized DPSCs (MDPSCs) and a collagen scaffold was utilized (Nakashima and Iohara, 2014). Upon autologous transplantation with the composite into the root canals of canine mature teeth after pulpectomy, vasculature and innervation- regenerated pulp-like tissue was formed with odontoblast-like cells on the surface of the root dentinal wall and newly formed dentin along the dentinal wall. It suggests that complete dental pulp regeneration similar to healthy dental pulp is achieved along with restoration of tooth function. The rarity of adverse events has confirmed the safety of MDPSCbased REPs. The biological characteristics of MDPSCs do not vary with age, including their stability and regenerative potential. Thus, MDPSCs have been applied to a clinical study to further explore the therapeutic potential and clinical safety of autologous MDPSC transplantation in pulpectomized human teeth (Nakashima et al., 2017). The results show mineralized structure formation of cone beam computed tomography (CBCT), similar signal intensity of magnetic resonance imaging to that of normal dental pulp in untreated controls, robust positive response of a pulp vitality test, and minor adverse events or toxicity. Therefore, human MDPSCs are suggested as safe and efficacious dental MSCs candidates in cell-based REPs.

The therapeutic potential of DPSCs in pulp-dentin regeneration via cell-based REPs is also explored in a minipig pulpectomy model with empty root canals (Xuan et al., 2018). The whole functional pulp tissue regenerates in root canals after implantation of DPSC aggregates harvested from minipigs, consisting of an odontoblast-like layer, blood vessels, and nerves. Based on the preclinical trial with a large animal model, they further conducted a randomized clinical controlled trial to determine the therapeutic effect on immature permanent tooth injuries caused by trauma (Xuan et al., 2018). Those immature 
TABLE 3 | Current preclinical and clinical studies of REPs based on dental MSCs.

\begin{tabular}{|c|c|c|c|c|c|c|c|c|c|}
\hline \multirow[t]{2}{*}{ Study/year } & \multirow{2}{*}{$\begin{array}{l}\text { Type of dental } \\
\text { MSCs }\end{array}$} & \multicolumn{6}{|c|}{ Experiment design } & \multicolumn{2}{|r|}{ Results or outcomes } \\
\hline & & Animal model & Defects & $\begin{array}{c}\text { Route of } \\
\text { administration }\end{array}$ & $\begin{array}{l}\text { Biomaterial/ } \\
\text { scaffold }\end{array}$ & Growth factors & $\begin{array}{l}\text { Observation } \\
\text { period }\end{array}$ & $\begin{array}{c}\text { Tissue } \\
\text { regeneration }\end{array}$ & $\begin{array}{l}\text { Effect evaluation and safety } \\
\text { assessment }\end{array}$ \\
\hline \multicolumn{10}{|c|}{ Preclinical studies } \\
\hline $\begin{array}{l}\text { lohara et al., } \\
2010\end{array}$ & $\begin{array}{l}\text { CD } 105+\text { canine } \\
\text { DPSCs }\end{array}$ & $\begin{array}{l}60 \text { incisors; } 15 \\
\text { dogs }\end{array}$ & $\begin{array}{l}\text { whole pulp removal; } \\
\text { enlargement of apical } \\
\text { foramen to } 0.7 \mathrm{~mm}\end{array}$ & $\begin{array}{l}\text { Autologous } \\
\text { transplantation; } \\
\text { root canal }\end{array}$ & $\begin{array}{c}\text { Mixture of } \\
\text { collagen type I } \\
\text { \& III }\end{array}$ & $\begin{array}{l}\text { Stromal cell-derived } \\
\text { factor-1 (SDF-1) }\end{array}$ & 14-90 days & $\begin{array}{l}\text { Functional } \\
\text { dental pulp }\end{array}$ & $\begin{array}{l}\text { HE: regenerative pulp with well } \\
\text { vasculature and innervation on day } 14\end{array}$ \\
\hline $\begin{array}{l}\text { lohara et al., } \\
2012\end{array}$ & Canine DPSCs & $\begin{array}{l}72 \text { incisors; } 18 \\
\text { dogs }\end{array}$ & $\begin{array}{l}\text { The whole pulp tissue } \\
\text { was removed, and the } \\
\text { root canals were } \\
\text { enlarged to open the } \\
\text { apical foramen to } \\
\text { 0.6mmin width in } \\
\text { incisors }\end{array}$ & $\begin{array}{l}\text { Autologous } \\
\text { transplantation; } \\
\text { root canal }\end{array}$ & $\begin{array}{l}\text { Atelocollagen } \\
\text { scaffold }\end{array}$ & $\begin{array}{l}\text { Granulocyte-colony } \\
\text { stimulating factor } \\
\text { (G-CSF) }\end{array}$ & $14-180$ days & $\begin{array}{l}\text { Functional } \\
\text { dental pulp }\end{array}$ & $\begin{array}{l}\text { Safety: no adverse effects on both the } \\
\text { whole and local } \\
\text { HE: regenerative pulp with well } \\
\text { vasculature and innervation on day } 14 \\
\text { RG: complete obliteration of the } \\
\text { enlarged apical portion and lateral and } \\
\text { coronal dentin formation } \\
\text { Laser Doppler: functional recovery of } \\
\text { pulpal blood flow after } 90 \text { days } \\
\text { Pulp vitality: positive response on day } \\
60 \text { and day } 180\end{array}$ \\
\hline $\begin{array}{l}\text { lohara et al., } \\
2014\end{array}$ & $\begin{array}{l}\text { canine mobilized } \\
\text { DPSCs }\end{array}$ & $\begin{array}{l}16 \text { incisors; } 4 \\
\text { dogs }\end{array}$ & $\begin{array}{l}\text { Whole pulp removed, } \\
\text { apical foramen } \\
\text { enlarged to } 0.5 \mathrm{~mm}\end{array}$ & $\begin{array}{l}\text { Autologous } \\
\text { transplantation; } \\
\text { root canal }\end{array}$ & $\begin{array}{l}\text { Atelocollagen } \\
\text { scaffold }\end{array}$ & $\begin{array}{l}\text { Granulocyte-colony } \\
\text { stimulating factor } \\
\text { (G-CSF) }\end{array}$ & $14-120$ days & $\begin{array}{l}\text { Functional } \\
\text { dental pulp }\end{array}$ & $\begin{array}{l}\text { HE: regenerative pulp with well } \\
\text { vasculature and innervation on day } 14 \\
\text { RG: complete obliteration of the } \\
\text { enlarged apical portion and lateral and } \\
\text { coronal dentin formation }\end{array}$ \\
\hline $\begin{array}{l}\text { Nakashima and } \\
\text { lohara, } 2014\end{array}$ & $\begin{array}{l}\text { Canine mobilized } \\
\text { DPSCs }\end{array}$ & - & $\begin{array}{l}\text { Root canals after } \\
\text { pulpectomy }\end{array}$ & $\begin{array}{l}\text { Autologous } \\
\text { transplantation; } \\
\text { root canal }\end{array}$ & $\begin{array}{l}\text { Drug-approved } \\
\text { collagen }\end{array}$ & $\begin{array}{l}\text { Granulocyte-colony } \\
\text { stimulating factor } \\
\text { (G-CSF) }\end{array}$ & $14-180$ days & $\begin{array}{l}\text { Pulp-like } \\
\text { tissue }\end{array}$ & $\begin{array}{l}\text { Safety: no adverse effects, no } \\
\text { inflammatory cells infiltrated, and no } \\
\text { internal or external resorption of the } \\
\text { tooth } \\
\text { HE: pulplike tissue with well vasculature } \\
\text { and innervation was regenerated } \\
14 \text { days } \\
\text { RG: complete obliteration of the } \\
\text { enlarged apical portion and lateral and } \\
\text { coronal dentin formation }\end{array}$ \\
\hline $\begin{array}{l}\text { El Ashiry et al., } \\
2018\end{array}$ & Canine DPSCs & $\begin{array}{l}36 \text { incisors; } 12 \\
\text { dogs }\end{array}$ & $\begin{array}{l}\text { Pulps from } \\
\text { crown and root }\end{array}$ & $\begin{array}{l}\text { Autologous } \\
\text { transplantation; } \\
\text { root canal }\end{array}$ & $\begin{array}{l}\text { Chitosan } \\
\text { hydrogel } \\
\text { scaffold }\end{array}$ & $\begin{array}{l}\text { Vascular endothelial } \\
\text { growth factor (VEGF-2), } \\
\text { basic fibroblast growth } \\
\text { factor (bFGF), } \\
\text { platelet-derived growth } \\
\text { factor (PDGF), nerve } \\
\text { growth factor (NGF), } \\
\text { bone } \\
\text { Morphogenetic } \\
\text { protein-7 (BMP7) }\end{array}$ & 1-4 months & $\begin{array}{l}\text { Vascularized } \\
\text { pulp- dentin } \\
\text { like tissue }\end{array}$ & $\begin{array}{l}\text { HE: delicate fibrous tissue resembling } \\
\text { the pulp tissue inside the root canal } \\
\text { containing multiple large and small } \\
\text { blood vessels; newly formed dentin-like } \\
\text { tissue with dentinal tubule-like } \\
\text { structures along the dentinal walls of } \\
\text { the root canal; the regenerated } \\
\text { dentin-like tissue did not form } \\
\text { well-organized dentinal tubules } \\
\text { RGE: closure of the root apex, } \\
\text { thickening of the root canal wall, and } \\
\text { prolongation of the root lengthening }\end{array}$ \\
\hline
\end{tabular}


TABLE 3 | Continued

\begin{tabular}{|c|c|c|c|c|c|c|c|c|c|}
\hline \multirow[t]{2}{*}{ Study/year } & \multirow{2}{*}{$\begin{array}{l}\text { Type of dental } \\
\text { MSCs }\end{array}$} & \multicolumn{6}{|c|}{ Experiment design } & \multicolumn{2}{|r|}{ Results or outcomes } \\
\hline & & Animal model & Defects & $\begin{array}{c}\text { Route of } \\
\text { administration }\end{array}$ & $\begin{array}{l}\text { Biomaterial/ } \\
\text { scaffold }\end{array}$ & Growth factors & $\begin{array}{l}\text { Observation } \\
\text { period }\end{array}$ & $\begin{array}{l}\text { Tissue } \\
\text { regeneration }\end{array}$ & $\begin{array}{l}\text { Effect evaluation and safety } \\
\text { assessment }\end{array}$ \\
\hline $\begin{array}{l}\text { Xuan et al., } \\
2018\end{array}$ & Pig DPSCs & minipigs & $\begin{array}{l}\text { Empty root canals after } \\
\text { pulpectomy }\end{array}$ & $\begin{array}{l}\text { DPSC } \\
\text { aggregates; } \\
\text { autologous } \\
\text { transplantation; } \\
\text { root canals }\end{array}$ & - & - & 3 months & $\begin{array}{l}\text { Whole pulp } \\
\text { tissue }\end{array}$ & $\begin{array}{l}\text { HE: regenerated pulp tissue containing } \\
\text { an odontoblast layer and blood vessels } \\
\text { IHC: NeuN }\end{array}$ \\
\hline \multirow[t]{2}{*}{ Study/year } & Type of dental & \multicolumn{6}{|c|}{ Experiment design } & \multicolumn{2}{|r|}{ Results or outcomes } \\
\hline & & $\begin{array}{l}\text { No. of } \\
\text { subjects } \\
\text { (teeth) }\end{array}$ & Defects & $\begin{array}{c}\text { Route of } \\
\text { administration }\end{array}$ & $\begin{array}{l}\text { Biomaterial/ } \\
\text { scaffold }\end{array}$ & Growth factors & $\begin{array}{l}\text { Observation } \\
\text { period }\end{array}$ & $\begin{array}{c}\text { Tissue } \\
\text { regeneration }\end{array}$ & $\begin{array}{l}\text { Effect evaluation and safety } \\
\text { assessment }\end{array}$ \\
\hline \multicolumn{10}{|c|}{ Clinical studies } \\
\hline $\begin{array}{l}\text { Nakashima } \\
\text { et al., } 2017\end{array}$ & $\begin{array}{l}\text { Human mobilized } \\
\text { DPSCs }\end{array}$ & $\begin{array}{l}5 \text { teeth (2 } \\
\text { incisors, } 3 \\
\text { premolars); } 5 \\
\text { patients with } \\
\text { irreversible } \\
\text { pulpitis }\end{array}$ & $\begin{array}{l}\text { Root canals after } \\
\text { pulpectomy }\end{array}$ & $\begin{array}{l}\text { Autologous } \\
\text { transplantation; } \\
\text { root canal }\end{array}$ & $\begin{array}{l}\text { Atelocollagen } \\
\text { scaffold }\end{array}$ & $\begin{array}{l}\text { Granulocyte } \\
\text { colony-stimulating } \\
\text { factor (G-CSF) }\end{array}$ & $\begin{array}{l}1,2,4,12, \text { and } \\
24 / 28 / 32 \\
\text { weeks }\end{array}$ & $\begin{array}{l}\text { Pulp-like } \\
\text { tissue }\end{array}$ & $\begin{array}{l}\text { Safety:no adverse events; no } \\
\text { postoperative pain, including } \\
\text { percussion pain and tenderness; no } \\
\text { significant changes in the periapical } \\
\text { areas } \\
\text { EPT: positive responses after } 4 \text { weeks } \\
\text { in } 4 \text { patients; } 1 \text { patient demonstrated a } \\
\text { negative response after } 24 \text { weeks } \\
\text { RG: obliteration of the enlarged apical } \\
\text { portion at } 24 / 28 \text { weeks in } 3 \text { patients } \\
\text { CBCT: lateral dentin formation at } \\
28 \text { weeks in } 3 \text { patients } \\
\text { MRI: regenerated tissue in the root } \\
\text { canal after } 24 \text { weeks was similar to that } \\
\text { of normal dental pulp in } 4 \text { patients }\end{array}$ \\
\hline $\begin{array}{l}\text { Xuan et al., } \\
2018\end{array}$ & Human DPSCs & $\begin{array}{l}26 \text { incisors; } 36 \\
\text { patients }\end{array}$ & $\begin{array}{l}\text { Dental trauma } \\
\text { with pulp } \\
\text { necrosis }\end{array}$ & $\begin{array}{l}\text { Two hDPSC } \\
\text { Aggregates; } \\
\text { Autologous } \\
\text { implantation; } \\
\text { Root canals }\end{array}$ & - & Extracellular matrix & $\begin{array}{l}1,3,6,9,12 \text {, } \\
\text { and } 24 \text { months }\end{array}$ & $\begin{array}{l}\text { Whole dental } \\
\text { pulp }\end{array}$ & $\begin{array}{l}\text { Safety: no significant side effects after } \\
12 \text { months } \\
\text { HE: regeneration of } 3 D \text { whole dental } \\
\text { pulp tissue } \\
\text { Digital RVG: no inflammation at the } \\
\text { periapical area and continued root } \\
\text { development after } 24 \text { months } \\
\text { EPT: decrease in sensation thresholds } \\
\text { CBCT: apical foramen width decreased, } \\
\text { the length of the treated tooth root } \\
\text { increased } \\
\text { Laser Doppler: increase in vascular } \\
\text { formation }\end{array}$ \\
\hline
\end{tabular}

HE, hematoxylin and eosin staining; IHC, immunohistochemical staining; RG, radiographic examination; RVG, radiovisiography; EPT, electric pulp vitality testing; CBCT, cone beam computed tomography. 
necrotic permanent teeth were transplanted autologously with DPSCs collected from primary teeth. Taking apexification as a control group, DPSC-treated immature permanent teeth presented with eliminated apical periodontitis and continued root formation during two years' follow-up. This was indicated by decreased apical foramen width and increased root length via CBCT, and dentin thickness increased via 3-D reconstruction. The viability of DPSC-treated teeth was validated by laser Doppler flowmetry and electric pulp testing, which showed an increase in vascular formation and decrease in sensation thresholds compared with controls. More excitingly, histological analysis of further traumatized teeth showed regeneration of pulp-dentin complex with an odontoblast layer. Thus, this study demonstrates better efficacy and safety of DPSCs implantation in cell-based REPs, in which 3-D dental pulp tissue with vasculature and innervation was regenerated. Besides, the efficacy and safety of allogenic umbilical cord MSCs have been proved in a preclinical trial (Brizuela et al., 2020). Other cell populations, such as SCAP or non-dental cells might also be useful in cell-based REPs. Considering the accessibility of cell sources, allogeneic cell sources are more usable.

\section{Challenge for Cell-Based REPs}

Cell-based REPs show promising outcomes in pulp-dentin regeneration. Several cell-based REPs are at the stage of clinical studies (Nakashima et al., 2017; Xuan et al., 2018), but transplantation of stem cells is still not recommended by either the American Association of Endodontists [AAE] (2018) or the European Society of Endodontology (ESE) (Galler et al., 2016). Multiple problems needed to be resolved before clinical application of stem cell transplantation, including isolation of stem cells, expansion of cells in vitro, practice facilities with good manufacturing, skill of clinicians, training of chair-side assistants, and high cost (Huang et al., 2013). MSCs are one of the most important elements in regenerative endodontics. However, their source and potency are still restrained due to the limitation of our available knowledge. In vitro- cultured human somatic stem cells, such as DPSCs, will end up with replicative senescence, a terminal state, after limited cell divisions (Kang et al., 2004). It is suggested that there is a notable elevation of senescent DPSCs cultured in vitro and an obvious reduction of odontogenic differentiation potential that may be attributed to loss of stem cell marker, Bmil (Mehrazarin et al., 2011). Besides, a large number of cell doublings with homogeneous loss of differentiation potential are required for cell transplantation with ex vivo expansion of DPSCs. Due to the aging-related change in DPSCs in the dental tissue of aged patients, the accessibility of DPSCs suitable for regeneration is restricted to immature permanent teeth of young patients. Therefore, lack of DPSCs from pulp tissue would make cell-based REPs in adult permanent teeth difficult to achieve. The ex vivo expansion of autologous MSCs in dental appointments with high time restrictions requires practice facilities with good manufacturing, and the procedure is always accompanied by high costs. In this context, allogeneic DPSCs may serve as a potential alternative, which can be produced in high volume and manipulated ready for REPs in the clinic. The immunomodulatory effects of allogeneic MSCs are suggested to be of importance in inflammatory disorders. Allogenic umbilical cord MSCs have been used for mature permanent teeth with combination of plasma-derived biomaterials, showing acceptable safety and efficacy in a phase $1 / 2$ clinical trial (Brizuela et al., 2020). Although transplantation of allogeneic MSCs in REPs shows promising prospects, more research is needed regarding immunogenicity, long-term outcomes, and safety.

\section{CONCLUSION}

Cell-free REPs, including revascularization and cell homing with molecules recruiting endogenous MSCs, are successful in resolving apical periodontitis and arrested root formation, which are eventually clinical regenerative endodontics and widely applied in treating immature permanent teeth with necrotic pulp. However, histological studies show that pulpdentin complex is absent in these cases although some studies show a positive response to vitality testing. Instead, cell-based REPs with dental MSCs have shown potential with pulp-dentin regeneration in large animal studies and clinical trials through cell transplantation. Before clinical translation of cell-based REPs, more research is still needed regarding isolation of stem cells, expansion of cells in vitro, good practice facilities, skills of clinicians, training of assistants, and reduction of costs. It is hoped that, when cell-based REPs realize true regeneration, they can be applied to the management of necrotic immature permanent teeth, resulting in long-term survival of patients' natural teeth and dentition.

\section{AUTHOR CONTRIBUTIONS}

DC and MW conceived the idea and designed the work. SY made the figures. XZ, YL, and YP integrated the materials. LZ revised the manuscript. DC wrote the manuscript. MW revised the manuscript critically. All authors have read and approved the final manuscript.

\section{FUNDING}

This work was supported by the National Natural Science Foundation of China (NSFC) Grant 81800929 and Sichuan Science and Technology Program 2019JDRC0096 to MW; National Natural Science Foundation of China (NSFC) Grant 81771033 and Research and Develop Program, West China Hospital of Stomatology Sichuan University, LCYJ2019-24 to LZ.

\section{REFERENCES}

Aimetti, M., Ferrarotti, F., Gamba, M. N., Giraudi, M., and Romano, F. (2018). Regenerative treatment of periodontal intrabony defects using autologous

dental pulp stem cells: a 1-year follow-up case series. Int. J. Periodontics Restorative Dent. 38, 51-58. doi: 10.11607/prd.3425

Ajram, J., Khalil, I., Gergi, R., and Zogheib, C. (2019). Management of an immature necrotic permanent molar with apical periodontitis treated by regenerative 
endodontic protocol using calcium hydroxide and MM-MTA: a case report with two years follow up. Dent. J. 7:1. doi: 10.3390/dj7010001

Al Ansary, M. A., Day, P. F., Duggal, M. S., and Brunton, P. A. (2009). Interventions for treating traumatized necrotic immature permanent anterior teeth: inducing a calcific barrier \& root strengthening. Dent. Traumatol. 25, 367-379. doi: 10.1111/j.1600-9657.2009.00797.x

Alasqah, M., Khan, S. I. R., Alfouzan, K., and Jamleh, A. (2020). Regenerative endodontic management of an immature molar using calcium hydroxide and triple antibiotic paste: a two-year follow-up. Case Rep. Dent. 2020:9025847. doi: 10.1155/2020/9025847

Alobaid, A. S., Cortes, L. M., Lo, J., Nguyen, T. T., Albert, J., Abu-Melha, A. S., et al. (2014). Radiographic and clinical outcomes of the treatment of immature permanent teeth by revascularization or apexification: a pilot retrospective cohort study. J. Endod. 40, 1063-1070. doi: 10.1016/j.joen.2014.02.016

Altaii, M., Cathro, P., Broberg, M., and Richards, L. (2017). Endodontic regeneration and tooth revitalization in immature infected sheep teeth. Int. Endod. J. 50, 480-491. doi: 10.1111/iej.12645

American Association of Endodontists [AAE] (2016a). AAE Endodontist's Glossary of Endodontic Terms. Avaliable at: https://www.aae.org/specialty/clinicalresources/glossary-endodontic-terms (accessed January 5, 2021).

American Association of Endodontists [AAE] (2016b). Regenerative Endodontics. Avaliable at: https://www.aae.org/specialty/newsletter/regenerativeendodontics (accessed January 5, 2021).

American Association of Endodontists [AAE] (2018). Clinical Considerations for a Regenerative Procedure. Avaliable at: https: //www.aae.org/uploadedfiles/publications_and_research/research/ currentregenerativeendodonticconsiderations.pdf (accessed January 5, 2021).

Andreasen, J. O., and Bakland, L. K. (2011). Pulp regeneration after non-infected and infected necrosis, what type of tissue do we want? A review. Dent. Traumatol. 28, 13-18. doi: 10.1111/j.1600-9657.2011.01057.x

Andreasen, J. O., Kristerson, I., and Andreasen, F. M. (1988). Damage of the Hertwig's epithelial root sheath: effect upon root growth after autotransplantation of teeth in monkeys. Endod. Dent. Traumatol. 4, 145-151. doi: 10.1111/j.1600-9657.1988.tb00313.x

Anitua, E., Troya, M., and Zalduendo, M. (2017). Progress in the use of dental pulp stem cells in regenerative medicine. Cytotherapy 20, 479-498. doi: 10.1016/j. jcyt.2017.12.011

Austah, O., Joon, R., Fath, W. M., Chrepa, V., Diogenes, A., Ezeldeen, M., et al. (2018). Comprehensive characterization of 2 immature teeth treated with regenerative endodontic procedures. J. Endod. 44, 1802-1811. doi: 10.1016/j. joen.2018.09.007

Banchs, F., and Trope, M. (2004). Revascularization of immature permanent teeth with apical periodontitis: new treatment protocol? J. Endod. 30, 196-200. doi: 10.1097/00004770-200404000-00003

Becerra, P., Ricucci, D., Loghin, S., Gibbs, J. L., and Lin, L. M. (2013). Histologic study of a human immature permanent premolar with chronic apical abscess after revascularization/revitalization. J. Endod. 40, 133-139. doi: 10.1016/j.joen. 2013.07.017

Beldi, G., Bahiraii, S., Lezin, C., Nouri Barkestani, M., Abdelgawad, M. E., Uzan, G., et al. (2020a). TNFR2 is a crucial hub controlling mesenchymal stem cell biological and functional properties. Front. Cell Dev. Biol. 8:596831. doi: 10. 3389/fcell.2020.596831

Beldi, G., Khosravi, M., Abdelgawad, M. E., Salomon, B. L., Uzan, G., Haouas, H., et al. (2020b). TNF $\alpha /$ TNFR2 signaling pathway: an active immune checkpoint for mesenchymal stem cell immunoregulatory function. Stem Cell Res Ther. 11:281. doi: 10.1186/s13287-020-01740-5

Bezgin, T., Yilmaz, A. D., Celik, B. N., Kolsuz, M. E., and Sonmez, H. (2014). Efficacy of platelet-rich plasma as a scaffold in regenerative endodontic treatment. J. Endod. 41, 36-44. doi: 10.1016/j.joen.2014.10.004

Bose, R., Nummikoski, P., and Hargreaves, K. (2009). A retrospective evaluation of radiographic outcomes in immature teeth with necrotic root canal systems treated with regenerative endodontic procedures. J. Endod. 35, 1343-1349. doi: 10.1016/j.joen.2009.06.021

Brizuela, C., Meza, G., Urrejola, D., Quezada, M. A., Concha, G., Ramírez, V., et al. (2020). Cell-based regenerative endodontics for treatment of periapical lesions: a randomized, controlled phase i/ii clinical trial. J. Dent. Res. 99, 523-529. doi: $10.1177 / 0022034520913242$
Chen, M. Y., Chen, K. L., Chen, C. A., Tayebaty, F., Rosenberg, P. A., and Lin, L. M. (2011). Responses of immature permanent teeth with infected necrotic pulp tissue and apical periodontitis/abscess to revascularization procedures. Int. Endod. J. 45, 294-305. doi: 10.1111/j.1365-2591.2011.01978.x

Cooper, P. R., Holder, M. J., and Smith, A. J. (2014). Inflammation and regeneration in the dentin-pulp complex: a double-edged sword. J. Endod. 40(4 Suppl.), S46-S51. doi: 10.1016/j.joen.2014.01.021

Cooper, P. R., Takahashi, Y., Graham, L. W., Simon, S., Imazato, S., and Smith, A. J. (2010). Inflammation-regeneration interplay in the dentin-pulp complex. J. Dent. 38, 687-697. doi: 10.1016/j.jdent.2010.05.016

Cordeiro, M. M., Dong, Z., Kaneko, T., Zhang, Z., Miyazawa, M., Shi, S., et al. (2008). Dental pulp tissue engineering with stem cells from exfoliated deciduous teeth. J. Endod. 34, 962-969. doi: 10.1016/j.joen.2008.04.009

da Silva, G. S., Moreira, M. S., Fukushima, K. A., Raggio, D. P., V Mello-Moura, A. C., Lara, J. S., et al. (2019). Current evidence of tissue engineering for dentine regeneration in animal models: a systematic review. Regen. Med. 15, 1345-1360. doi: 10.2217/rme-2019-0005

da Silva, L. A., Nelson-Filho, P., da Silva, R. A., Flores, D. S., Heilborn, C., Johnson, J. D., et al. (2009). Revascularization and periapical repair after endodontic treatment using apical negative pressure irrigation versus conventional irrigation plus triantibiotic intracanal dressing in dogs' teeth with apical periodontitis. Oral. Surg. Oral. Med. Oral. Pathol. Oral. Radiol. Endod. 109, 779-787. doi: 10.1016/j.tripleo.2009.12.046

De Berdt, P., Vanacker, J., Ucakar, B., Elens, L., Diogenes, A., Leprince, J. G., et al. (2015). Dental apical papilla as therapy for spinal cord injury. J. Dent. Res. 94, 1575-1581. doi: 10.1177/0022034515604612

Ding, R. Y., Cheung, G. S., Chen, J., Yin, X. Z., Wang, Q. Q., and Zhang, C. F. (2009). Pulp revascularization of immature teeth with apical periodontitis: a clinical study. J. Endod. 35, 745-749. doi: 10.1016/j.joen.2009.02.009

Diogenes, A., and Hargeraves, K. M. (2017). Microbial modulation of stem cells and future directions in regenerative endodontics. J. Endod. 43, S95-S101. doi: 10.1016/j.joen.2017.07.012

Diogenes, A., Ruparel, N. B., Shiloah, Y., and Hargreaves, K. M. (2016). Regenerative endodontics: a way forward. J. Am. Dent. Assoc. 147, 372-380. doi: 10.1016/j.adaj.2016.01.009

Dominici, M., Le Blanc, K., Mueller, I., Slaper-Cortenbach, I., Marini, F., Krause, D., et al. (2006). Minimal criteria for defining multipotent mesenchymal stromal cells. The international society for cellular therapy position statement. Cytotherapy 8, 315-317. doi: 10.1080/14653240600855905

El Ashiry, E. A., Alamoudi, N. M., El Ashiry, M. K., Bastawy, H. A., El Derwi, D. A., and Atta, H. M. (2018). Tissue engineering of necrotic dental pulp of immature teeth with apical periodontitis in dogs: radiographic and histological evaluation. J. Clin. Pediatr. Dent. 42, 373-382. doi: 10.17796/1053-4625-42.5.9

Eramo, S., Natali, A., Pinna, R., and Milia, E. (2018). Dental pulp regeneration via cell homing. Int. Endod. J. 51, 405-419. doi: 10.1111/iej.12868

Ferrarotti, F., Romano, F., Gamba, M. N., Quirico, A., Giraudi, M., Audagna, M., et al. (2018). Human intrabony defect regeneration with micrografts containing dental pulp stem cells: a randomized controlled clinical trial. J. Clin. Periodontol. 45, 841-850. doi: 10.1111/jcpe. 12931

Galler, K. M., Krastl, G., Simon, S., Van Gorp, G., Meschi, N., Vahedi, B., et al. (2016). European society of endodontology position statement: revitalization procedures. Int. Endod. J. 49, 717-723. doi: 10.1111/iej.12629

Gronthos, S., Mankani, M., Brahim, J., Robey, P. G., and Shi, S. (2000). Postnatal human dental pulp stem cells (DPSCs) in vitro and in vivo. Proc, Natl. Acad. Sci. U.S.A. 97, 13625-13630. doi: 10.1073/pnas.240309797

Han, C., Yang, Z., Zhou, W., Jin, F., Song, Y., Wang, Y., et al. (2009). Periapical follicle stem cell: a promising candidate for cementum/periodontal ligament regeneration and bio-root engineering. Stem Cells Dev. 19, 1405-1415. doi: $10.1089 / \mathrm{scd} .2009 .0277$

Han, Y., Li, X., Zhang, Y., Han, Y., Chang, F., and Ding, J. (2019). Mesenchymal stem cells for regenerative medicine. Cells 8:886. doi: 10.3390/cells8080886

He, L., Zhong, J., Gong, Q., Cheng, B., Kim, S. G., Ling, J., et al. (2016). Regenerative endodontics by cell homing. Dent. Clin. North Am. 61, 143-159. doi: 10.1016/j. cden.2016.08.010

Hernández-Monjaraz, B., Santiago-Osorio, E., Ledesma-Martínez, E., AlcauterZavala, A., and Mendoza-Núñez, V. M. (2018). Retrieval of a periodontally compromised tooth by allogeneic grafting of mesenchymal stem cells from 
dental pulp: a case report. J. Int. Med. Res. 46, 2983-2993. doi: 10.1177/ 0300060518773244

Hoshino, E., Kurihara-Ando, N., Sato, I., Uematsu, H., Sato, M., Kota, K., et al. (1996). In-vitro antibacterial susceptibility of bacteria taken from infected root dentine to a mixture of ciprofloxacin, metronidazole and minocycline. Int. Endod. J. 29, 125-130. doi: 10.1111/j.1365-2591.1996.tb01173.x

Huang, G. T., Al-Habib, M., and Gauthier, P. (2013). Challenges of stem cell-based pulp and dentin regeneration: a clinical perspective. Endod Top. 28, 51-60. doi: $10.1111 /$ etp. 12035

Huang, G. T., Gronthos, S., and Shi, S. (2009a). Mesenchymal stem cells derived from dental tissues vs. those from other sources: their biology and role in regenerative medicine. J. Dent. Res. 88, 792-806. doi: 10.1177/ 0022034509340867

Huang, G. T., Yamaza, T., Shea, L. D., Djouad, F., Kuhn, N. Z., Tuan, R. S., et al. (2010). Stem/progenitor cell-mediated de novo regeneration of dental pulp with newly deposited continuous layer of dentin in an in vivo model. Tissue Eng. Part A 16, 605-615. doi: 10.1089/ten.TEA.2009.0518

Huang, X., Bringas, P. Jr., Slavkin, H. C., and Chai, Y. (2009). Fate of HERS during tooth root development. Dev. Biol. 334, 22-30. doi: 10.1016/j.ydbio.2009. 06.034

Iohara, K., Imabayashi, K., Ishizaka, R., Watanabe, A., Nabekura, J., Ito, M., et al. (2010). Complete pulp regeneration after pulpectomy by transplantation of CD105+ stem cells with stromal cell-derived factor-1. Tissue Eng. Part A. 17, 1911-1920. doi: 10.1089/ten.TEA.2010.0615

Iohara, K., Murakami, M., Nakata, K., and Nakashima, M. (2014). Age-dependent decline in dental pulp regeneration after pulpectomy in dogs. Exp. Gerontol. 52, 39-45. doi: 10.1016/j.exger.2014.01.020

Iohara, K., Murakami, M., Takeuchi, N., Osako, Y., Ito, M., Ishizaka, R., et al. (2012). A novel combinatorial therapy with pulp stem cells and granulocyte colony-stimulating factor for total pulp regeneration. Stem Cells Transl. Med. 2, 521-533. doi: 5966/sctm.2012-0132

Iohara, K., Zheng, L., Ito, M., Ishizaka, R., Nakamura, H., Into, T., et al. (2009). Regeneration of dental pulp after pulpotomy by transplantation of CD31()/CD146(-) side population cells from a canine tooth. Regen. Med. 4, 377-385. doi: $10.2217 / \mathrm{rme} .09 .5$

Iwasaki, K., Akazawa, K., Nagata, M., Komaki, M., Honda, I., Morioka, C., et al. (2019). The fate of transplanted periodontal ligament stem cells in surgically created periodontal defects in rats. Int. J. Mol. Sci. 20:192. doi: 10.3390/ ijms20010192

Iwata, T., Yamato, M., Zhang, Z., Mukobata, S., Washio, K., Ando, T., et al. (2010). Validation of human periodontal ligament-derived cells as a reliable source for cytotherapeutic use. J. Clin, Periodontol. 37, 1088-1099. doi: 10.1111/j.1600051X.2010.01597.x

Iwaya, S., Ikawa, M., and Kubota, M. (2001). Revascularization of an immature permanent tooth with apical periodontitis and sinus tract. Dent. Traumatol. 17, 185-187. doi: 10.1034/j.1600-9657.2001.017004185.x

Iwaya, S., Ikawa, M., and Kubota, M. (2010). Revascularization of an immature permanent tooth with periradicular abscess after luxation. Dent. Traumatol. 27, 55-58. doi: 10.1111/j.1600-9657.2010.00963.x

Jadhav, G. R., Shah, N., and Logani, A. (2013). Comparative outcome of revascularization in bilateral, non-vital, immature maxillary anterior teeth supplemented with or without platelet rich plasma: a case series. J. Conserv. Dent. 16, 568-572. doi: 10.4103/0972-0707.120932

Jeeruphan, T., Jantarat, J., Yanpiset, K., Suwannapan, L., Khewsawai, P., and Hargreaves, K. M. (2012). Mahidol study 1: comparison of radiographic and survival outcomes of immature teeth treated with either regenerative endodontic or apexification methods: a retrospective study. J. Endod. 38, 1330-1336. doi: 10.1016/j.joen.2012.06.028

Jeong, S. Y., Lee, S., Choi, W. H., Jee, J. H., Kim, H. R., and Yoo, J. (2020). Fabrication of dentin-pulp-like organoids using dental-pulp stem cells. Cells 9:642. doi: 10.3390/cells9030642

Johnson, R. W. (1997). Inhibition of growth by pro-inflammatory cytokines: an integrated view. J. Anim. Sci. 75, 1244-1255. doi: 10.2527/1997.755 $1244 \mathrm{x}$

Jung, J., Kim, J. W., Moon, H. J., Hong, J. Y., and Hyun, J. K. (2016). Characterization of neurogenic potential of dental pulp stem cells cultured in xeno/serum-free condition: in vitro and in vivo assessment. Stem Cells Int. 2016:6921097. doi: 10.1155/2016/6921097
Kahler, B., Mistry, S., Moule, A., Ringsmuth, A. K., Case, P., Thomson, A., et al. (2013). Revascularization outcomes: a prospective analysis of 16 consecutive cases. J. Endod. 40, 333-338. doi: 10.1016/j.joen.2013.10.032

Kang, M. K., Kameta, A., Shin, K. H., Baluda, M. A., and Park, N. H. (2004). Senescence occurs with hTERT repression and limited telomere shortening in human oral keratinocytes cultured with feeder cells. J. Cell Physiol. 199, 364-370. doi: 10.1002/jcp.10410

Kawase-Koga, Y., Fujii, Y., Yamakawa, D., Sato, M., and Chikazu, D. (2019). Identification of neurospheres generated from human dental pulp stem cells in xeno-/serum-free conditions. Regen. Ther. 14, 128-135. doi: 10.1016/j.reth. 2019.11.006

Khademi, A. A., Dianat, O., Mahjour, F., Razavi, S. M., and Younessian, F. (2014). Outcomes of revascularization treatment in immature dog's teeth. Dent. Traumatol. 30, 374-379. doi: 10.1111/edt.12100

Kim, D. S., Park, H. J., Yeom, J. H., Seo, J. S., Ryu, G. J., Park, K. H., et al. (2012). Long-term follow-ups of revascularized immature necrotic teeth: three case reports. Int. J. Oral. Sci. 4, 109-113. doi: 10.1038/ijos.2012.23

Kim, J. Y., Xin, X., Moioli, E. K., Chung, J., Lee, C. H., Chen, M., et al. (2010). Regeneration of dental-pulp-like tissue by chemotaxis-induced cell homing. Tissue Eng. Part A. 16, 3023-3031. doi: 10.1089/ten.TEA.2010.0181

Kling, M., Cvek, M., and Mejare, I. (1986). Rate and predictability of pulp revascularization in therapeutically reimplanted permanent incisors. Endod Dent, Traumatol. 2, 83-89. doi: 10.1111/j.1600-9657.1986.tb00132.x

Kunimatsu, R., Nakajima, K., Awada, T., Tsuka, Y., Abe, T., Ando, K., et al. (2018). Comparative characterization of stem cells from human exfoliated deciduous teeth, dental pulp, and bone marrow-derived mesenchymal stem cells. Biochem. Biophys, Res. Commun. 501, 193-198. doi: 10.1016/j.bbrc.2018.04.213

Liu, C., Xiong, H., Chen, K., Huang, Y., Huang, Y., and Yin, X. (2016). Long-term exposure to pro-inflammatory cytokines inhibit the osteogenic/dentinogenic differentiation of stem cells from the apical papilla. Int. Endod. J. 49, 950-959. doi: 10.1111/iej.12551

Liu, J. Y., Chen, X., Yue, L., Huang, G. T., and Zou, X. Y. (2015). Cxc chemokine receptor 4 is expressed paravascularly in apical papilla and coordinates with stromal cell-derived factor-1alpha during transmigration of stem cells from apical papilla. J. Endod. 41, 1430-1436. doi: 10.1016/j.joen.2015.04.006

Londero Cde, L., Pagliarin, C. M., Felippe, M. C., Felippe, W. T., Danesi, C. C., and Barletta, F. B. (2015). Histologic analysis of the influence of a gelatinbased scaffold in the repair of immature dog teeth subjected to regenerative endodontic treatment. J. Endod. 41, 1619-1625. doi: 10.1016/j.joen.2015.01.033

Lovelace, T. W., Henry, M. A., Hargreaves, K. M., and Diogenes, A. (2010). Evaluation of the delivery of mesenchymal stem cells into the root canal space of necrotic immature teeth after clinical regenerative endodontic procedure. J. Endod. 37, 133-138. doi: 10.1016/j.joen.2010.10.009

Martin, G., Ricucci, D., Gibbs, J. L., and Lin, L. M. (2012). Histological findings of revascularized/revitalized immature permanent molar with apical periodontitis using platelet-rich plasma. J. Endod. 39, 138-144. doi: 10.1016/j.joen.2012.09. 015

McCulloch, C. A., and Melcher, A. H. (1983). Cell density and cell generation in the periodontal ligament of mice. Am. J, Anat. 167, 43-58. doi: 10.1002/aja. 1001670105

Mehrazarin, S., Oh, J. F., Chung, C. L., Chen, W., Kim, R. H., Shi, S. T., et al. (2011). Impaired odontogenic differentiation of senescent dental mesenchymal stem cells is associated with loss of Bmi-1 expression. J. Endod. 37, 662-666. doi: 10.1016/j.joen.2011.02.009

Meza, G., Urrejola, D., Saint Jean, N., Inostroza, C., López, V., Khoury, M., et al. (2018). Personalized cell therapy for pulpitis using autologous dental pulp stem cells and leukocyte platelet-rich fibrin: a case report. J. Endod. 45, 144-149. doi: 10.1016/j.joen.2018.11.009

Miura, M., Gronthos, S., Zhao, M., Lu, B., Fisher, L. W., Robey, P. G., et al. (2003). SHED: stem cells from human exfoliated deciduous teeth. Proc. Natl. Acad. Sci. U.S.A. 100, 5807-5812. doi: 10.1073/pnas.0937635100

Mooney, D. J., Powell, C., Piana, J., and Rutherford, B. (1996). Engineering dental pulp-like tissue in vitro. Biotechnol. Prog. 12, 865-868. doi: 10.1021/bp960073f

Morsczeck, C., Götz, W., Schierholz, J., Zeilhofer, F., Kühn, U., Möhl, C., et al. (2004). Isolation of precursor cells (PCs) from human dental follicle of wisdom teeth. Matrix Biol. 24, 155-165. doi: 10.1016/j.matbio.2004.12.004

Mortada, I., and Mortada, R. (2018). Dental pulp stem cells and osteogenesis: an update. Cytotechnology 70, 1479-1486. doi: 10.1007/s10616-018-0225-5 
Murray, P. E., Garcia-Godoy, F., and Hargreaves, K. M. (2006). Regenerative endodontics: a review of current status and a call for action. J. Endod. 33, 377-390. doi: 10.1016/j.joen.2006.09.013

Nagata, J. Y., Gomes, B. P., Rocha Lima, T. F., Murakami, L. S., de Faria, D. E., Campos, G. R., et al. (2014). Traumatized immature teeth treated with 2 protocols of pulp revascularization. J. Endod. 40, 606-612. doi: 10.1016/j.joen. 2014.01.032

Nagy, M. M., Tawfik, H. E., Hashem, A. A., and Abu-Seida, A. M. (2013). Regenerative potential of immature permanent teeth with necrotic pulps after different regenerative protocols. J. Endod. 40, 192-198. doi: 10.1016/j.joen.2013. 10.027

Nakashima, M., and Akamine, A. (2005). The application of tissue engineering to regeneration of pulp and dentin in endodontics. J. Endod. 31, 711-718. doi: 10.1097/01.don.0000164138.49923.e5

Nakashima, M., and Iohara, K. (2014). Mobilized dental pulp stem cells for pulp regeneration: initiation of clinical trial. J. Endod. 40(4 Suppl.), S26-S32. doi: 10.1016/j.joen.2014.01.020

Nakashima, M., Iohara, K., Murakami, M., Nakamura, H., Sato, Y., Ariji, Y., et al. (2017). Pulp regeneration by transplantation of dental pulp stem cells in pulpitis: a pilot clinical study. Stem Cell Res. Ther. 8:61. doi: 10.1186/s13287017-0506-5

Narang, I., Mittal, N., and Mishra, N. (2015). A comparative evaluation of the blood clot, platelet-rich plasma, and platelet-rich fibrin in regeneration of necrotic immature permanent teeth: a clinical study. Contemp. Clin. Dent. 6, 63-68. doi: 10.4103/0976-237X.149294

Naserian, S., Abdelgawad, M. E., Afshar Bakshloo, M., Ha, G., Arouche, N., Cohen, J. L., et al. (2020). The TNF/TNFR2 signaling pathway is a key regulatory factor in endothelial progenitor cell immunosuppressive effect. Cell Commun. Signal. 18:94. doi: 10.1186/s12964-020-00564-3

Nicola, F., Marques, M. R., Odorcyk, F., Petenuzzo, L., Aristimunha, D., Vizuete, A., et al. (2018). Stem cells from human exfoliated deciduous teeth modulate early astrocyte response after spinal cord contusion. Mol. Neurobiol. 56, 748-760. doi: 10.1007/s12035-018-1127-4

Nicoloso, G. F., Pötter, I. G., Rocha, R. O., Montagner, F., and Casagrande, L. (2017). A comparative evaluation of endodontic treatments for immature necrotic permanent teeth based on clinical and radiographic outcomes: a systematic review and meta-analysis. Int. J. Paediatr. Dent. 27, 217-227. doi: 10.1111/ipd.12261

Noronha, N. D. C., Mizukami, A., Caliári-Oliveira, C., Cominal, J. G., Rocha, J. L. M., Covas, D. T., et al. (2019). Priming approaches to improve the efficacy of mesenchymal stromal cell-based therapies. Stem Cell Res. Ther. 10:131. doi: 10.1186/s13287-019-1224-y

Nosrat, A., Kolahdouzan, A., Hosseini, F., Mehrizi, E. A., Verma, P., and Torabinejad, M. (2015). Histologic outcomes of uninfected human immature teeth treated with regenerative endodontics: 2 case reports. J. Endod. 41, 1725-1729. doi: 10.1016/j.joen.2015.05.004

Nosrat, A., Seifi, A., and Asgary, S. (2011). Regenerative endodontic treatment (revascularization) for necrotic immature permanent molars: a review and report of two cases with a new biomaterial. J. Endod. 37, 562-567. doi: 10.1016/ j.joen.2011.01.011

Nygaard-Ostby, B. (1961). The role of the blood clot in endodontic therapy. An experimental histologic study. Acta Odontol. Scand. 19, 324-353.

Nygaard-Ostby, B., and Hjortdal, O. (1971). Tissue formation in the root canal following pulp removal. Scand. J. Dent. Res. 79, 333-349. doi: 10.1111/j.16000722.1971.tb02019.x

Pagella, P., Miran, S., Neto, E., Martin, I., Lamghari, M., and Mitsiadis, T. A. (2019). Human dental pulp stem cells exhibit enhanced properties in comparison to human bone marrow stem cells on neurites outgrowth. FASEB J. 34, 5499-5511. doi: 10.1096/fj.201902482R

Pelissari, C., Paris, A. F. C., Mantesso, A., and Trierveiler, M. (2018). Apical papilla cells are capable of forming a pulplike tissue with odontoblastlike cells without the use of exogenous growth factors. J. Endod. 44, 1671-1676. doi: 10.1016/j. joen.2018.08.005

Petrino, J. A., Boda, K. K., Shambarger, S., Bowles, W. R., and McClanahan, S. B. (2009). Challenges in regenerative endodontics: a case series. J. Endod. 36, 536-541. doi: 10.1016/j.joen.2009.10.006
Pittenger, M. F., Mackay, A. M., Beck, S. C., Jaiswal, R. K., Douglas, R., and Mosca, J. D. (1999). Multilineage potential of adult human mesenchymal stem cells. Science 284, 143-147. doi: 10.1126/science.284.5411.143

Rafter, M. (2004). Apexification: a review. Dent. Traumatol. 21, 1-8. doi: 10.1111/j. 1600-9657.2004.00284.x

Reynolds, K., Johnson, J. D., and Cohenca, N. (2008). Pulp revascularization of necrotic bilateral bicuspids using a modified novel technique to eliminate potential coronal discolouration: a case report. Int. Endod. J. 42, 84-92. doi: 10.1111/j.1365-2591.2008.01467.x

Rizk, H. M., Al-Deen, M. S. S., and Emam, A. A. (2019). Regenerative endodontic treatment of bilateral necrotic immature permanent maxillary central incisors with platelet-rich plasma versus blood clot: a split mouth double-blinded randomized controlled trial. Int. J. Clin. Pediatr. Dent. 12, 332-339. doi: 10. 5005/jp-journals- 10005-1656

Rodríguez-Benítez, S., Stambolsky, C., Gutiérrez-Pérez, J. L., Torres-Lagares, D., and Segura-Egea, J. J. (2015). Pulp revascularization of immature dog teeth with apical periodontitis using triantibiotic paste and platelet-rich plasma: a radiographic study. J. Endod. 41, 1299-1304. doi: 10.1016/j.joen.2015.05.002

Rustad, K. C., and Gurtner, G. C. (2011). Mesenchymal stem cells home to sites of injury and inflammation. Adv. Wound Care 1, 147-152. doi: 10.1089/wound. 2011.0314

Sakai, V. T., Zhang, Z., Dong, Z., Neiva, K. G., Machado, M. A., Shi, S., et al. (2010). SHED differentiate into functional odontoblasts and endothelium. J. Dent. Res. 89, 791-796. doi: 10.1177/0022034510368647

Saoud, T. M., Zaazou, A., Nabil, A., Moussa, S., Aly, H. M., Okazaki, K., et al. (2015). Histological observations of pulpal replacement tissue in immature dog teeth after revascularization of infected pulps. Dent. Traumatol. 31, 243-249. doi: 10.1111/edt.12169

Saoud, T. M., Zaazou, A., Nabil, A., Moussa, S., Lin, L. M., and Gibbs, J. L. (2014). Clinical and radiographic outcomes of traumatized immature permanent necrotic teeth after revascularization/revitalization therapy. J. Endod. 40, 19461952. doi: 10.1016/j.joen.2014.08.023

Seo, B. M., Miura, M., Gronthos, S., Bartold, P. M., Batouli, S., Brahim, J., et al. (2004). Investigation of multipotent postnatal stem cells from human periodontal ligament. Lancet 364, 149-155. doi: 10.1016/S0140-6736(04) 16627-0

Shabahang, S. (2012). Treatment options: apexogenesis and apexification. J. Endod. 39(3 Suppl.), S26-S29. doi: 10.1016/j.joen.2012.11.046

Sharpe, P. T. (2016). Dental mesenchymal stem cells. Development 143, 2273-2280. doi: 10.1242/dev.134189

Shimizu, E., Jong, G., Partridge, N., Rosenberg, P. A., and Lin, L. M. (2012) Histologic observation of a human immature permanent tooth with irreversible pulpitis after revascularization/regeneration procedure. J. Endod. 38, 12931297. doi: 10.1016/j.joen.2012.06.017

Shimizu, E., Ricucci, D., Albert, J., Alobaid, A. S., Gibbs, J. L., Huang, G. T., et al. (2013). Clinical, radiographic, and histological observation of a human immature permanent teeth with chronic apical abscess after revitalization treatment. J. Endod. 39, 1078-1083. doi: 10.1016/j.joen.2013.04.032

Sönmez, I. S., Akbay Oba, A., and Erkmen Almaz, M. (2013). Revascularization/Regeneration performed in immature molars: case reports. J. Clin. Pediatr. Dent. 37, 231-234. doi: 10.17796/jcpd.37.3.j6007761g8811453

Sonoyama, W., Liu, Y., Fang, D., Yamaza, T., Seo, B. M., Zhang, C., et al. (2006). Mesenchymal stem cell-mediated functional tooth regeneration in swine. PLoS One 1:e79. doi: 10.1371/journal.pone.0000079

Sonoyama, W., Liu, Y., Yamaza, T., Tuan, R. S., Wang, S., Shi, S., et al. (2007a). Characterization of the apical papilla and its residing stem cells from human immature permanent teeth: a pilot study. J. Endod. 34, 166-171. doi: 10.1016/j. joen.2007.11.021

Sonoyama, W., Seo, B. M., Yamaza, T., and Shi, S. (2007b). Human Hertwig's epithelial root sheath cells play crucial roles in cementum formation. J. Dent. Res. 86, 594-599. doi: 10.1177/154405910708600703

Suzuki, T., Lee, C. H., Chen, M., Zhao, W., Fu, S. Y., Qi, J. J., et al. (2011). Induced migration of dental pulp stem cells for in vivo pulp regeneration. J. Dent. Res. 90, 1013-1018. doi: 10.1177/0022034511408426

Tawfik, H., Abu-Seida, A. M., Hashem, A. A., and Nagy, M. M. (2013). Regenerative potential following revascularization of immature permanent teeth with necrotic pulps. Int. Endod. J. 46, 910-922. doi: 10.1111/iej.12079 
Thesleff, I., and Sharpe, P. (1997). Signalling networks regulating dental development. Mech. Dev. 67, 111-123. doi: 10.1016/s0925-4773(97)00115-9

Thomson, A., and Kahler, B. (2010). Regenerative endodontics-biologically-based treatment for immature permanent teeth: a case report and review of the literature. Aust. Dent. J. 55, 446-452. doi: 10.1111/j.1834-7819.2010.01268.x

Tian, Y., Bai, D., Guo, W., Li, J., Zeng, J., Yang, L., et al. (2015). Comparison of human dental follicle cells and human periodontal ligament cells for dentin tissue regeneration. Regen. Med. 10, 461-479. doi: 10.2217/rme.15.21

Timmerman, A., and Parashos, P. (2016). Delayed root development by displaced mineral trioxide aggregate after regenerative endodontics: a case report. J. Endod. 43, 252-256. doi: 10.1016/j.joen.2016.10.024

Torabinejad, M., and Faras, H. (2012). A clinical and histological report of a tooth with open apex treated with regenerative endodontics using platelet-rich plasma. J. Endod. 38, 864-868. doi: 10.1016/j.joen.2012.03.006

Torabinejad, M., Milan, M., Shabahang, S., Wright, K. R., and Faras, H. (2015). Histologic examination of teeth with necrotic pulps and periapical lesions treated with 2 scaffolds: an animal investigation. J. Endod. 41, 846-852. doi: 10.1016/j.joen.2015.01.026

Torabinejad, M., and Turman, M. (2010). Revitalization of tooth with necrotic pulp and open apex by using platelet-rich plasma: a case report. J. Endod. 37, 265-268. doi: 10.1016/j.joen.2010.11.004

Trubiani, O., Pizzicannella, J., Caputi, S., Marchisio, M., Mazzon, E., Paganelli, R., et al. (2019). Periodontal ligament stem cells: current knowledge and future perspectives. Stem Cells Dev. 28, 995-1003. doi: 10.1089/scd.2019.0025

Ulusoy, A. T., Turedi, I., Cimen, M., and Cehreli, Z. C. (2019). Evaluation of blood clot, platelet-rich plasma, platelet-rich fibrin, and platelet pellet as scaffolds in regenerative endodontic treatment: a prospective randomized trial. J. Endod. 45, 560-566. doi: 10.1016/j.joen.2019.02.002

Wang, F., Jiang, Y., Huang, X., Liu, Q., Zhang, Y., Luo, W., et al. (2017). Proinflammatory cytokines TNF-a attenuates BMP9-induced osteo/odontoblasts differentiation of the stem cells of dental apical papilla. Cell Physiol. Biochem. 41, 1725-1735. doi: 10.1159/000471865

Wang, J., Wang, X., Sun, Z., Wang, X., Yang, H., Shi, S., et al. (2009). Stem cells from human-exfoliated deciduous teeth can differentiate into dopaminergic neuron-like cells. Stem Cells Dev. 19, 1375-1383. doi: 10.1089/scd.2009. 0258

Xuan, K., Li, B., Guo, H., Sun, W., Kou, X., He, X., et al. (2018). Deciduous autologous tooth stem cells regenerate dental pulp after implantation into injured teeth. Sci. Transl. Med. 10:eaaf3227. doi: 10.1126/scitranslmed.aaf 3227

Yamauchi, N., Yamauchi, S., Nagaoka, H., Duggan, D., Zhong, S., Lee, S. M., et al. (2010). Tissue engineering strategies for immature teeth with apical periodontitis. J. Endod. 37, 390-397. doi: 10.1016/j.joen.2010.11.010

Yildirim, S., Zibandeh, N., Genc, D., Ozcan, E. M., Goker, K., and Akkoc, T. (2016). The comparison of the immunologic properties of stem cells isolated from human exfoliated deciduous teeth, dental pulp, and dental follicles. Stem Cells Int. 2016:4682875. doi: 10.1155/2016/4682875

Yin, Y., Li, X., He, X. T., Wu, R. X., Sun, H. H., and Chen, F. M. (2017). Leveraging stem cell homing for therapeutic regeneration. J. Dent. Res. 96, 601-609. doi: 10.1177/0022034517706070

Yoo, Y. J., Lee, W., Cho, Y. A., Park, J. C., Shon, W. J., and Baek, S. H. (2014). Effect of conditioned medium from preameloblasts on regenerative cellular differentiation of the immature teeth with necrotic pulp and apical periodontitis. J. Endod. 40, 1355-1361. doi: 10.1016/j.joen.2014.02.009

Zeichner-David, M., Oishi, K., Su, Z., Zakartchenko, V., Chen, L. S., Arzate, H., et al. (2003). Role of Hertwig's epithelial root sheath cells in tooth root development. Dev. Dyn. 228, 651-663. doi: 10.1002/dvdy.10404

Zhang, D. D., Chen, X., Bao, Z. F., Chen, M., Ding, Z. J., and Zhong, M. (2014). Histologic comparison between platelet-rich plasma and blood clot in regenerative endodontic treatment: an animal study. J. Endod. 40, 1388-1393. doi: 10.1016/j.joen.2014.03.020

Zhou, T., Pan, J., Wu, P., Huang, R., Du, W., Zhou, Y., et al. (2019). Dental follicle cells: roles in development and beyond. Stem Cells Int. 2019:9159605. doi: $10.1155 / 2019 / 9159605$

Conflict of Interest: The authors declare that the research was conducted in the absence of any commercial or financial relationships that could be construed as a potential conflict of interest.

Copyright (C) 2021 Cui, Yu, Zhou, Liu, Gan, Pan, Zheng and Wan. This is an openaccess article distributed under the terms of the Creative Commons Attribution License (CC BY). The use, distribution or reproduction in other forums is permitted, provided the original author(s) and the copyright owner(s) are credited and that the original publication in this journal is cited, in accordance with accepted academic practice. No use, distribution or reproduction is permitted which does not comply with these terms. 